\title{
Improvement of the consideration of seismic risks in Algerian planning and urban development instruments: application to the Boumerdés region (50km east of Algiers /Algeria).
}

\author{
Mohamed Yacine Kheliouen ${ }^{1}$ and Abdelmadjd Bouder ${ }^{2}$
}

\author{
${ }^{1}$ Architect and Research Professor, Institute of Urban Architecture / University of Blida (Algeria). kheliouen.yacine@yahoo.fr \\ 2 Professor, Director of Research, Laboratory of Urban Geography and Land Use Planning / University of Science and Technology \\ of Algiers (Algeria). abouder@yahoo.fr
}

\begin{abstract}
The territory of both Algiers and Boumerdés departments was hit in 2003 by a violent earthquake of 6.8 (M) causing considerable human and material losses. In order to establish preventive solutions, the article recommend the seismic risk studies to be considered in national and urban planning instruments, It presents a seismic vulnerability study applied to three (03) cities located in the region that have high populations and challenges Two assessments are presented for each city: the first consists of studying the vulnerability of buildings to the earthquake using a qualitative empirical method called Risk-EU. The second assessment focuses on the unbuilt part of the city through the analysis of evacuation and rescue capacity after the earthquake. This latter is a method used in the seismic micro zoning study of the wilaya of Algiers that was jointly established by 02 Japanese and Algerian study centers. The superposition of the summary vulnerability maps of the two assessments designed using a geographic information system (GIS), shows us the location of the most vulnerable urban areas. Damage of the building is coupled with their degree of isolation that serves for evacuation and rescue in the case of an earthquake. The results of cumulative vulnerability (built and urban system) at the scale of the region studied, then at each city and districts, are shown graphically and statistically.
\end{abstract}

Keywords: Boumerdés, Dellys, Bordjménail, Instrument of development and urbanism, Vulnerability of the Building, Evacuation and rescue capacity, Cumulative seismic risk

\section{Introduction}

The aftermath of the Boumerdés earthquake in 2003 led the Algerian authorities to promulgate the Act No. 04$05 / 2004$ on urban planning and development and Act No. 04-20/2004 on major risk prevention and disaster management. Both laws were also responding to sustainable development. As a result, seismic risks in the Algerian planning and urban planning instruments become a preliminary obligation. The first and most preventive planning and urban development studies was established in the Boumerdés region after the 2003 earthquake. It showed the contribution of a mapping of natural hazards threatening the territories. It consists of a geological mapping of the soils or the classification of some urban areas affected by servitude not desirable for construction [1], without however providing an explicit consideration of seismic risks through the vulnerability analysis of existing buildings. This is fact, represents the cause of direct human and material losses and thus, the resilience capacity of cities known as a cumulative factor, in the indirect human and material losses.

This article is a contribution to complement and enrich the planning and urban development studies of Algerian cities with practical tools that allow not only a physical assessment of the damage associated with a probable scenario earthquake, but also the enhancement of the urban system to respond to evacuation and relief plans after the disaster. It comes after having completed the first step of evaluating the seismic-proof urban system in the region.

The analysis is applied to three (03) cities that are located in the region. The first part of this work consists of the study area presentation. The second part is devoted to the methodology adopted and to seismic risk assessment. The third part, shows how the superposition of vulnerability maps makes possible not only identifying the concentrations of sensitive urban areas but also a comparative reading of vulnerabilities. The study is expressed in a rich and varied graphic mode according to a hierarchical scale, region, cities and districts Finally, in the fourth part the possibility of integrating the content of the results with the nature of Algerian planning and urban development instruments is checked.

\section{Presentation of the study region}

The region that was damaged by the Boumerdés earthquake of 21 May 2003 consists of Three (03) municipalities in the department, wilaya of Boumerdés. That are; Boumerdés (50 km east of Algiers), Dellys (100 km east of Algiers) and Bordjménail ( $70 \mathrm{~km}$ east of Algiers).These municipalities were selected in relation to the classification of their seismic risks by the Algerian seismic rules RPA 99/2003[2], and in relation to their high urban concentration considered vulnerable (urban system and populations) (Table 1)

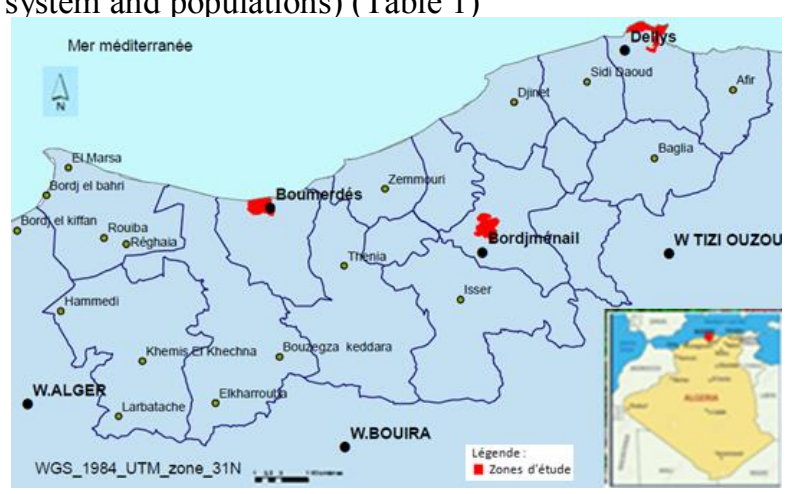

Figure 1: Image of the region and the cities Studie 
Table 1: Summary of population data and urban issues in the study area Source: (PAWB 2012)[6]

\begin{tabular}{|c|c|c|c|}
\hline & \begin{tabular}{|c} 
Population \\
(inhabitants) \\
2008/estimate \\
2019
\end{tabular} & $\begin{array}{c}\text { Urban } \\
\text { concentration } \\
\text { index } \\
\text { (Ic) }\end{array}$ & $\begin{array}{c}\text { Classification } \\
\text { according } \\
\text { to RPA } \\
99 / 2003\end{array}$ \\
\hline Dellys & $\begin{array}{c}32954 / \\
38681\end{array}$ & $\begin{array}{l}\text { Concentrated } \\
\text { area with } \\
\text { medium } \\
\text { density } \\
0>(\text { Ic })<2 \\
\end{array}$ & $\begin{array}{c}\text { Zone III of } \\
\text { high } \\
\text { seismicity }\end{array}$ \\
\hline $\begin{array}{l}\text { Bordj- } \\
\text { Ménail }\end{array}$ & $64820 / 78438$ & $\begin{array}{l}\text { Concentrated } \\
\text { area with } \\
\text { medium } \\
\text { density } \\
0>\text { (Ic) }<2 \\
\end{array}$ & $\begin{array}{c}\text { Zone III of } \\
\text { high } \\
\text { seismicity }\end{array}$ \\
\hline Boumerdés & $41685 / 51772$ & $\begin{array}{l}\text { Dense area } \\
\text { with very high } \\
\text { concentration } \\
\text { (Ic) }>2\end{array}$ & $\begin{array}{c}\text { Zone III of } \\
\text { high } \\
\text { seismicity }\end{array}$ \\
\hline
\end{tabular}

\subsection{Construction typologies and seismic regulations adopted in the three (03) cities studied}

1.1.1 Before 1830: Dellys is the oldest town in the region under study. It consists of a Casbah (Citadel) dating from the 11 th century [3].Its houses built in two levels, are built in stone masonry rubble available in the region, and the floors are made of very old materials such as tree trunks with thick earth or composite local coatings laid on a wooden support and planks made in factory. This historic nucleus, which was badly damaged by the last earthquake of 21 May 2003, is now classified as a national heritage site to be safeguarded [4].

1.1.2 1830-1962: During the French colonization in the region between1845-1962, the region witnessed the extension of the city of Dellys, the birth of the first nuclei of the towns of Bordjménail and Rocher Noir (Boumerdés). Building system of the French colonists was characterized by masonry walls made of masonry or solid bricks and floors made of brick vaults and metal IPN. It was then substituted during the last decades of colonization with modern materials such as reinforced concrete and prefabricated brick. The first earthquake of the colonial era occurred in Orléon-ville (now Chlef, 200 $\mathrm{km}$ west of Algiers) on September 9, 1954 that had a magnitude of 7.It brought the French colonial authorities back to promulgate the first seismic regulation applied in the region entitled "AS 55 Recommendations"[5].

1.1.3 1962-Today: At the time of independence in 1962, the AS55 was the only seismic regulation applied in Algeria. he reinforced concrete framework with prefabricated bricks constituted the constructive typology adopted on the periphery of colonial urban centers. The disastrous earthquake of 1980, that had a magnitude Richter 7.3, hit again the city of El Asnam (now Chlef) and prompted the authorities to introduce the first Algerian earthquake regulation called RPA81.The most significant seismic activities recorded throughout the national territory in the late 1980s and during the 1990s led to the birth of two new regulations called respectively RPA88 and PPA 99. Finally, the last Boumerdés earthquake on May 21, 2003 having 6.8 in the Richter magnitude, brought back more preventive corrections to RPA99 that becomes now RPA99/ version 2003, that is the last regulation applied until now

\subsection{Nomenclature of existing construction typologies}

The constructions built before 1830 are summarized in the Kasbah of Dellys. Their nomenclature used for this work is (No Code.0). Buildings dating from the beginning of colonialism, in 1830, until the advent of the first seismic regulation applied in the region take the nomenclature of (Non Code.1).Constructions made in application of the obsolete seismic codes such as AS 55, RPA81 and RPA88/99 have a nomenclature of (Low code AS 55 and RPA81/1999). Finally, the new buildings built after the 2003 earthquake will have as nomenclature (High Code RPA1999/2003) (figure 2).

\subsection{Previous vulnerability studies in the study area (Dellys, Bordjménail and Boumerdés)}

Following the Boumerdés earthquake on May 21, 2003, the National Centre for Applied Research in Parasismic Engineering (CGS) and the National Technical Control Body for Construction (CTC) carried out a study for the "Emergency Assessment of Building Safety Levels" on 400,000 housing units in Algiers, and 16,000 units in the wilaya of Boumerdes (that includes the cities of Dellys, Bordjménail and Boumerdés). The survey covered buildings located in aselected areas of each city. The different types of structures are masonry, BA gantries, reinforced concrete shear walls and steel structure [7]. The reports of the CGS and CTC survey on the four types of structures in each municipality were used in the seismic micro zoning study of the wilaya of Algiers. It was prepared by the Japanese international agency JICA [8] and the study on the vulnerability and adaptation of the wilaya of Algiers to climate change and natural hazards [9].

Unlike the many studies of the vulnerability of the built environment on an urban scale that remain frequent in Algeria, studies of the vulnerability of the urban system (non-built elements) are totally inexistent for the studied area. (Dellys, Bordjménail and Boumerdés) as well as the majority of other Algerian cities, except the JICACGS study which presented an urban seismic risk assessment of thirty-four (34) municipalities in the wilaya of Algiers, are based on six evaluation criteria. 


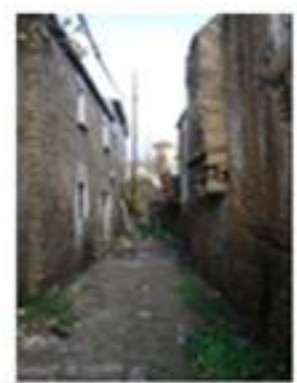

\section{Stone masonry (Nocode 0)}

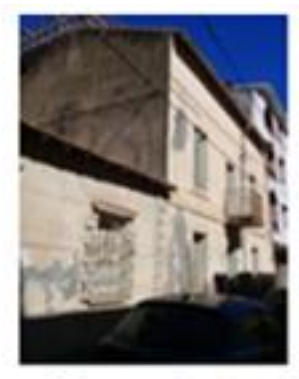

Matched stones masonry (No code 1)

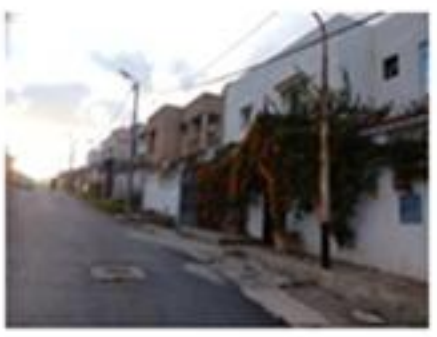

Reinforced concrete framework prefabricated briks (low code PS And RPA 81/88/99)

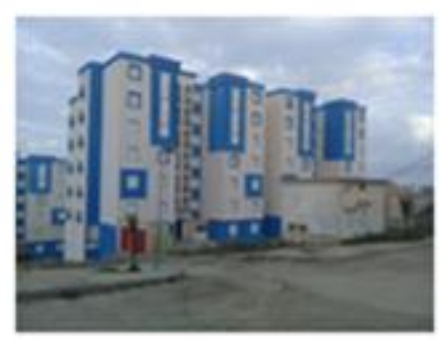

New constructions (high code RPA 99/2003)

Figure 2: Construction typologies and seismic code applied to the existing building (Photos by the authors)

Table 2: Quantitative distribution of construction typologies and seismic codes (Source: PDAU Dellys, Bordjménail and Boumerdés [1], and GIS calculation by the authors)

\begin{tabular}{|c|c|c|c|}
\hline $\begin{array}{c}\text { Constructive typology / Seismic } \\
\text { Code level }\end{array}$ & $\begin{array}{c}\text { Dellys } \\
\text { (Nbr/ Building unit) }\end{array}$ & $\begin{array}{c}\text { Bordjménail } \\
\text { (Nbr/ Building unit) }\end{array}$ & $\begin{array}{c}\text { Boumerdés } \\
\text { (Nbr/ Building } \\
\text { unit) }\end{array}$ \\
\hline $\begin{array}{c}\text { Structure braced by sails built } \\
\text { after 2003 } \\
\text { (High code RPA 99/2003) }\end{array}$ & 360 & 138 & 377 \\
\hline $\begin{array}{c}\text { Reinforced concrete frame with } \\
\text { masonry filling } \\
\text { (Low code PS55 and } \\
\text { RPA81/88/99) }\end{array}$ & 2071 & 2193 & 1219 \\
\hline $\begin{array}{c}\text { Load-bearing masonry walls } \\
\text { made of rubble stones with } \\
\text { advanced state of deterioration } \\
\text { (No code.0) }\end{array}$ & 393 & 0 & 0 \\
\hline $\begin{array}{c}\text { Masonry load-bearing walls } \\
\text { made of paired stones with a state } \\
\text { of Mayen degradation } \\
\text { (No code.1) }\end{array}$ & 180 & 365 & 13 \\
\hline $\begin{array}{c}\text { Prefabricated wooden chalet with } \\
\text { addition of adjoining buildings }\end{array}$ & 264 & 144 & \\
\hline Total & 3268 & 2840 & 1609 \\
\hline
\end{tabular}

\section{2- Adopted methodology and seismic risk assessment}

\section{2-1 Vulnerability assessment of the existing building}

The purpose of any method of assessing the seismic vulnerability of buildings is to provide a measure of the propensity of a building (or group of buildings) to suffer damage in the event of an earthquake. The analysis of the structural, geometric or technological characteristics that may influence building conduct is the object of such studies. Accordingly, Group 2 buildings according to the Algerian Parasismic Regulations (RPA99/2003) constitute the main part of the current buildings in the study area. As the exhaustive seismic diagnosis, building by building, is unrealistic, a larger scale analysis is indicated.
The existing methods of large-scale evaluations most commonly found in the bibliography (mainly American, European and Japanese) are numerous and include analyses of existing documents, visual diagnoses and feedback. These methods include the ATC and FEMA methods for the United States [10], the Italian GNDT method [11], and the European Risk-EU method [12]. They are all based on a structural typology, observed pathologies, and fragility or vulnerability curves based on observations made during destructive earthquakes. The latter provide the most likely level of damage achieved based on the seismic stress.

On the basis of these remarks, the Risk-EU method was adopted in our study. Developed as part of a European project and applied to seven cities: Bitola (Macedonia), 
Thessaloniki (Greece), Catania (Italy), Bucharest (Romania), Barcelona (Spain), Sofia (Bulgaria) and Nice (France). The latter shows a certain similarity between the old buildings of European cities and the cities under study. On the one hand, they are located in the Mediterranean region and on the other hand they have the colonial urban fabrics resulting from the French occupation of Algeria until 1962.

\subsubsection{The Risk-EU method level 1.0 (RUN1)}

The macro-seismic method (level 1) is based on the assessment of a vulnerability index for a given building, which depends on the constructive typology of the building as well as on different factors that can modify its conduct. From this index, it is possible to define vulnerability curves based on the macro-seismic intensity of the EMS-98 [13], which makes it possible to assess the distribution of the probability of damage to the building.

- The Building Vulnerability Index (VI): The Building Vulnerability Index (VI) is between 0 and 1; values close to 1 correspond to the most vulnerable buildings. It is obtained by summing three terms

$$
\mathrm{V}_{\mathrm{I}}=\mathrm{Vi}^{*}+\Delta \mathrm{Vm}+\Delta \mathrm{Vr}
$$

- $\mathrm{Vi}^{*}$ according to the typology of the building, read directly from the BTM (Building Typology Matrix) by a matrix in which a vulnerability index is assigned to each type of building. Twenty-three (23) building types are characterized in this matrix.

- $\Delta \mathrm{Vm}$ representing the aggravating factor that can modify the building's behaviour, read directly from the two tables relating to the construction typologies in reinforced concrete or masonry

- $\Delta \mathrm{Vr}$ Taking into account the expert's judgment regarding the regional particularities of the vulnerability suspected during the observation

- Average damage rate D: Estimating the probability that a group of buildings will reach a given level of damage for a given seismic intensity requires the calculation of an average damage rate. This average damage rate is calculated, based on the vulnerability index (V I) and seismic intensity (I), according to the following equation

$\mu_{\mathrm{D}}=2.5\left[1+\tanh \left(\frac{\mathrm{I}+6.25 \mathrm{~V}_{1}-13.1}{2.3}\right)\right]$

Table 3: Illustrations of damage levels on the European Macro seismic Scale (based on EMS98, 2001 and Giovinazzi and Lagomarsino, 2003) [13]
Vulnerability curves: The average damage equation defines the vulnerability curve. Figure 3.1 presents the vulnerability curves for the most common typologies of the RUN1 BTM. These curves link seismic stress, expressed in terms of macro-seismic intensity, to an average damage rate.

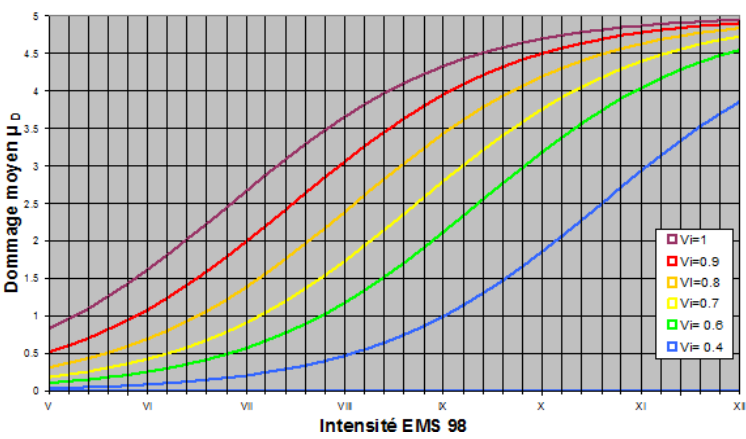

Figure 3.1: Mean vulnerability functions for different VI

\subsubsection{Application to the three cities under study}

- The values of the $\mathrm{Vi}^{*}$ vulnerability index identified in the BTM tables are presented in Table 4 for each constructive typology co-responding with the existing building. The $\Delta \mathrm{Vm}$ index only takes into account the level of the seismic code applied to the building as an aggravating factor of vulnerability, therefore $\Delta \mathrm{Vr}$ is equal to zero (0).

- The seismic intensity (I) is set at IX (09) using the SMC safety increased earthquake[14], which is one degree higher than the historical intensity known in the region, given that the earthquake of 21 May 2013 induced an intensity of damage close to VIII (08) according to the bibliography[15].

- The degree of seismic risk for each type of existing building is affected in relation to the level of average calcareous damage according to the grid in Table 4 and Figure 3.2. The degree of overall seismic risk for an urban area with varying levels of damage is determined according to the most vulnerable damage.

- Since individual constructions without building permits are tolerated in Algeria, in the absence of regulatory sanctions, the application of the seismic code remains non-obligatory for many self builders, so we note the difficulty of ensuring the application of the regulatory code RPA1999/2003 for this category which is very popular in Algerian cities. As a result, we have assigned the low code nomenclature PS 55 and RPA81/1999 for this part of the building.

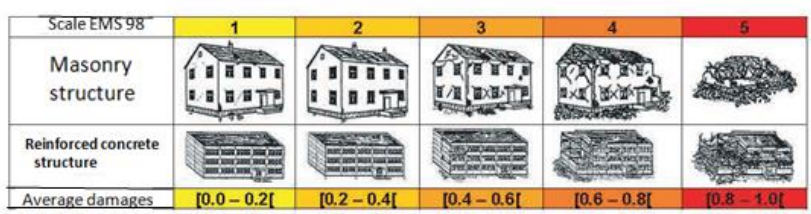


Table 4: Summary of numerical indices and evaluation criteria applied in the three cities

\begin{tabular}{|c|c|c|c|c|c|}
\hline $\begin{array}{l}\text { Construction typology - seismic } \\
\text { code level / BTM table } \\
\text { (Risk-EU method) }\end{array}$ & $\begin{array}{l}\text { Vulnerability } \\
\text { Index } \\
\text { (VI) }\end{array}$ & $\begin{array}{l}\text { Seismic } \\
\text { intensity } \\
\text { (I) }\end{array}$ & $\begin{array}{l}\text { Estimated } \\
\text { average } \\
\text { damage } \\
(\mu \mathrm{D})\end{array}$ & $\begin{array}{l}\text { Level of damage: } \\
\text { European Macro } \\
\text { seismic Scale } \\
\text { (EMS 98) } \\
\end{array}$ & $\begin{array}{r}\text { Degree } \\
\text { of seismic risk } \\
\text { of the existing } \\
\text { building }\end{array}$ \\
\hline $\begin{array}{c}\text { Structure braced by sails built after } \\
2003 \text { (High code RPA 99/2003)/ } \\
\text { (RC4) }\end{array}$ & 0.226 & $\begin{array}{l}\text { IX } \\
(9)\end{array}$ & 0.44 & $\begin{array}{l}\text { Negligible to light } \\
\text { damage (D1) } \\
\text { (no structural } \\
\text { damage) }\end{array}$ & Low risk \\
\hline $\begin{array}{c}\text { reinforced concrete frame with } \\
\text { masonry filling (Low code PS55 and } \\
\text { RPA81/88/99) / (RC3.1) }\end{array}$ & 0.76 & $\begin{array}{l}\text { IX } \\
(9)\end{array}$ & 3.18 & $\begin{array}{c}\text { Damage } \\
\text { moderate to } \\
\text { sensitive (D3) } \\
\text { (moderate } \\
\text { structural } \\
\text { damage) }\end{array}$ & Moderate risk \\
\hline $\begin{array}{l}\text { Load-bearing masonry walls made of } \\
\text { rubble stones with advanced state of } \\
\text { deterioration (No code. } 0) /(\mathrm{M} 1.1)\end{array}$ & 1.02 & $\begin{array}{l}\text { IX } \\
(9)\end{array}$ & 4.39 & $\begin{array}{l}\text { Very significant } \\
\text { damage } \\
\text { (D5) } \\
\text { (very significant } \\
\text { structural } \\
\text { damage) }\end{array}$ & High risk \\
\hline $\begin{array}{l}\text { Masonry load-bearing walls made of } \\
\text { paired stones with a state of Mayen } \\
\text { degradation (No code.1)/ (M1.2) }\end{array}$ & 0.83 & $\begin{array}{l}\text { IX } \\
(9)\end{array}$ & 3.6 & $\begin{array}{l}\text { Sensitive to } \\
\text { severe damage } \\
\text { [D4-D5 [ } \\
\text { (significant } \\
\text { structural } \\
\text { damage) }\end{array}$ & High risk \\
\hline $\begin{array}{l}\text { Prefabricated wooden chalet with } \\
\text { addition of adjoining buildings / (W) }\end{array}$ & 0.3 & $\begin{array}{l}\text { IX } \\
(9)\end{array}$ & 0.63 & $\begin{array}{l}\text { Negligible to } \\
\text { slight damage } \\
\text { (D1) } \\
\text { (no structural } \\
\text { damage) }\end{array}$ & Low risk \\
\hline
\end{tabular}

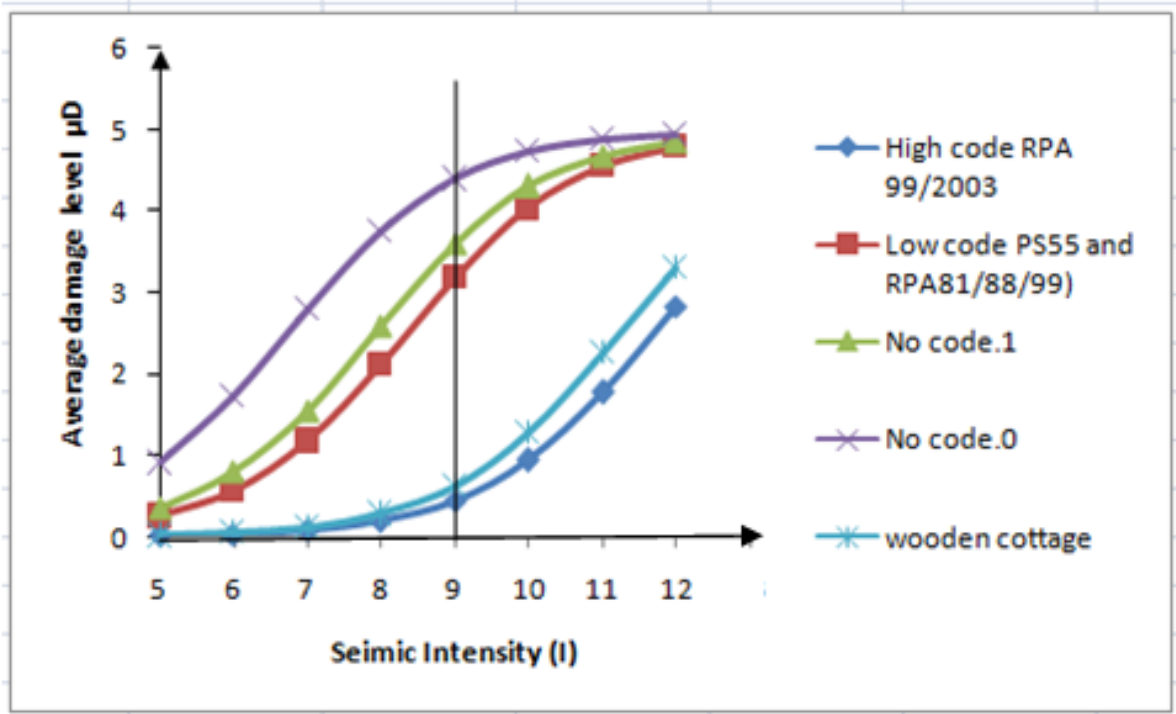

Figure 3.2: Vulnerability curves of existing buildings 


\subsection{Vulnerability assessment of the urban System}

Unlike the vulnerability assessment of the existing building, which witnessed the emergence of diversified approaches, the vulnerability assessment of the urban system has no standard or a reference methodology. However, the different assessments adopted around the world are often carried out taking into account local specificities of each city.In addition, the seismic microzoning study of the city of Algiers jointly prepared by the Japanese international agency "JICA" and the Algerian Research Centre "CGS" [9] presents an urban seismic risk assessment of thirty-four (34) municipalities. It is based on the evaluation of six criteria that are: population density, building age, Economic value, Potential for ground surface movement, Risk of slope failure and Emergency Evacuation, and Rescue Facility. The analysis was calculated using data from the Geographic Information System (GIS) based on experimental indices from experiences in Japan. The last criterion, "Emergency Evacuation and Rescue Facility" was adopted as the tool for assessing the seismic vulnerability of the urban system for our study..

\subsubsection{Presentation of the criterion: Evacuation and rescue facility}

- Classification of the road network:

- Roads appropriate for evacuation and rescue activities must have the appropriate following features:

- All roads $8 \mathrm{~m}$ wide or more.

- Roads with a width of $4 \mathrm{~m}$ to $8 \mathrm{~m}$ beyond the reach of any collapsed building.

- Of the roads meeting these two conditions, only those that form a continuous corridor in a regional road network have been identified as "appropriate" for evacuation and rescue activities.

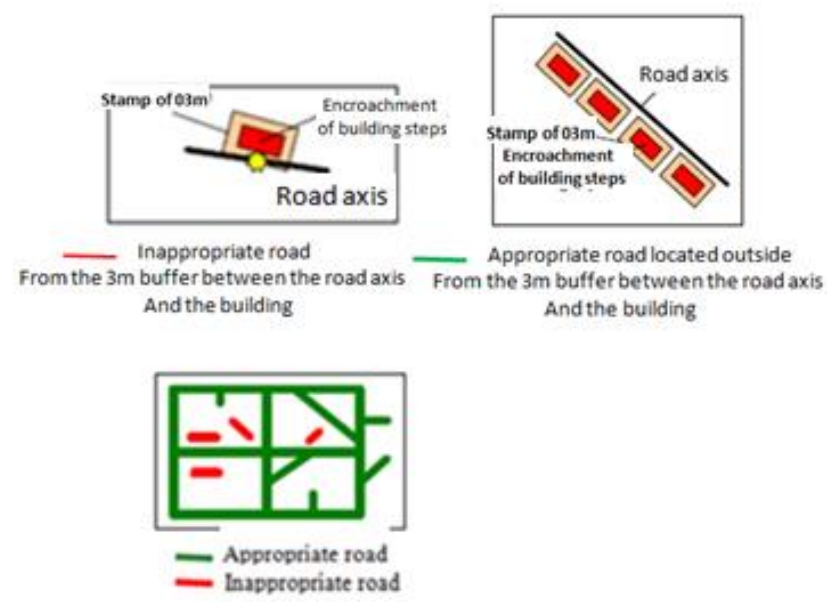

Figure 4: Conceptual views of "Appropriate" and "Inappropriate" roads (Source: JICA-CGS Study Team)

- Classification of urban areas connected by the evacuation and emergency road network: Each urban area under study is divided by an approximate grid to a cell measuring $250 \mathrm{~m} \times 250 \mathrm{~m}$. Urban areas joining the appropriate roads are set to "Appropriate Area" with a score of One (1), while those located near the inappropriate roads are classified as "Inappropriate Area", they are assigned the value zero (0). The evaluation is done in the Geographical Information System GIS (figure 5).

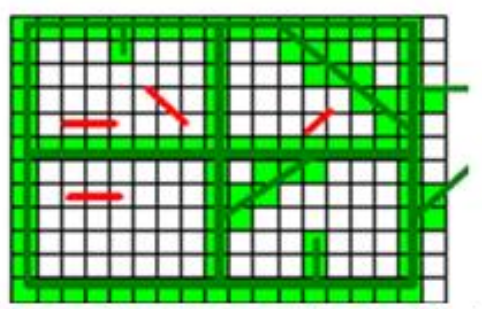

(1) Appropriate urban area (1); Low risk of isolation

Inappropriate urban area (0); High risk of isolation

Figure 5: Conceptual view of isolation risk by connecting to roads on the cell axis (Source: JICA-CGS Study Team)

Classification of urban areas connected by evacuation and emergency points:

The availability of evacuation points in the study area that can be used as shelters for disaster victims should have the following characteristics. The evaluation is done in the GIS (figure 6):

- A disaster management resource must have an area equal to or greater than one hectare (1) ha.

- A disaster management resource must include within its $500 \mathrm{~m}$ radius the urban area(s) to be served by the evacuation points.

- All evacuation points must be accessible through the network of evacuation routes described above.

- All evacuation points must be at least $250 \mathrm{~m}$ from equipment or a fuel tank.

- urban areas within a $500 \mathrm{~m}$ radius of a point suitable for rescue are classified as "appropriate" for evacuation and rescue, they are assigned a score of one (1), urban areas outside the $500 \mathrm{~m}$ radius, therefore inappropriate for evacuation and rescue, they are assigned a score of zero (0).

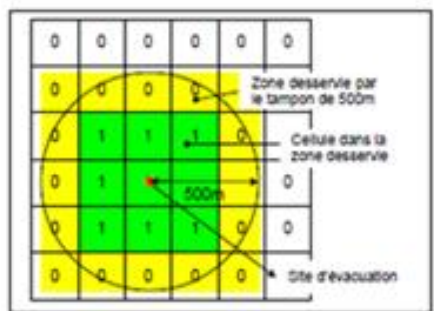

Appropriate urban area (1); Low risk of isolation Inappropriate urban area $(0)$ : High risk of isolation

Figure 6: Conceptual view of a $500 \mathrm{~m}$ wide buffer around an evacuation point (Source: JICA-CGS Study Team) 
- $\quad$ Classification of urban areas with access to evacuation and rescue

Each cell in the urban area mesh is assigned a new value according to the following formula:.

New cell value (accessibility value $)]=([$ Cell value connected by road network] x 2) $+[$ Cell value connected by evacuation points]

Using the above formula, the new value of the calculated cell would be one of four numbers: $0,1,2$ or 3 . the value zero ( 0$)$ corresponds to a cell not connected by the network of evacuation and emergency roads and not connected by evacuation points, the value 1 corresponds Evacuation and emergency points. Finally, the value 3 suggests that the cell should combine the connection to the network of evacuation and emergency roads and Emergency points, the value 2 indicates that the cell is well connected by the network of evacuation and emergency roads and vice versa, it is not connected by to a cell not connected by the network of evacuation and emergency roads yet it is connected by evacuation and evacuation and emergency points (figure 7). The evaluation is done in the GIS:
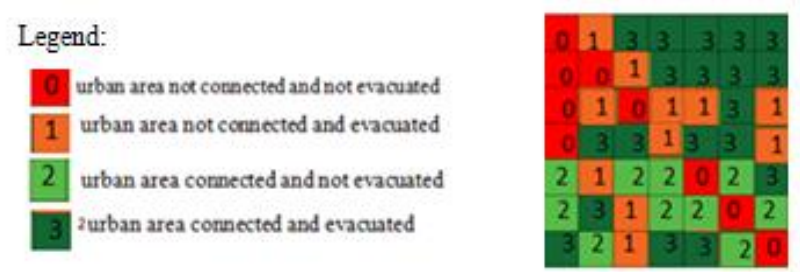

Figure 7: Schematic conceptual view of the accessibility values of the cells in the study area (Source: the author)

\subsubsection{Application to the three cities under study}

The degree of Seismic Risk for each evacuation and rescue accessibility value is affected according to the grid in Table 5:

\subsection{Overlay of the vulnerability map of the existing building on that of the accessibility capacity for evacuation and rescue}

The superposition of the two maps is expressed in relation to the cumulative degree of seismic risk; each urban cell in the study area is assigned a new nomenclature according to the grid in Table 6:
Table 5: Accessibility value and seismic risk level of Urban areas

\begin{tabular}{|c|c|c|c|}
\hline $\begin{array}{l}\text { Value of the } \\
\text { area } \\
\text { connected } \\
\text { by the road } \\
\text { network }\end{array}$ & $\begin{array}{l}\text { Value of the } \\
\text { area } \\
\text { connected } \\
\text { by } \\
\text { evacuation } \\
\text { points }\end{array}$ & $\begin{array}{c}\text { Accessibility } \\
\text { value of the } \\
\text { urban area }\end{array}$ & $\begin{array}{c}\text { Degree of } \\
\text { seismic risk } \\
\text { to } \\
\text { accessibility } \\
\text { to } \\
\text { evacuation } \\
\text { and rescue }\end{array}$ \\
\hline $\begin{array}{c}\text { Inappropriate } \\
\text { area }(0)\end{array}$ & $\begin{array}{c}\text { Inappropriate } \\
\text { area }(0)\end{array}$ & $\begin{array}{c}\text { Not } \\
\text { connected } \\
\text { and not } \\
\text { evacuated } \\
\text { area }(0)\end{array}$ & High risk \\
\hline $\begin{array}{c}\text { Inappropriate } \\
\text { area }(0)\end{array}$ & $\begin{array}{l}\text { Appropriate } \\
\text { area (1) }\end{array}$ & $\begin{array}{c}\text { Unconnected } \\
\text { and } \\
\text { Evacuable } \\
\text { area (1) }\end{array}$ & High risk \\
\hline $\begin{array}{l}\text { Appropriate } \\
\text { area (1) }\end{array}$ & $\begin{array}{c}\text { Inappropriate } \\
\text { area }(0)\end{array}$ & $\begin{array}{l}\text { Connected } \\
\text { and Not } \\
\text { Evacuated } \\
\text { Area (2) }\end{array}$ & $\begin{array}{l}\text { Moderate } \\
\text { risk }\end{array}$ \\
\hline $\begin{array}{l}\text { Appropriate } \\
\text { area (1) }\end{array}$ & $\begin{array}{l}\text { Appropriate } \\
\text { area (1) }\end{array}$ & $\begin{array}{l}\text { Connected } \\
\text { and } \\
\text { Evacuated } \\
\text { Area (3) }\end{array}$ & Low risk \\
\hline
\end{tabular}


Table 6: Final value of the cumulative seismic risk of urban area

\begin{tabular}{|c|c|c|c|}
\hline Risk level by Criteria & $\begin{array}{c}\text { Degree of cumulative seismic risk } \\
\text { (Building and accessibility value) }\end{array}$ & $\begin{array}{c}\text { Cumulative } \\
\text { Degree }\end{array}$ & $\begin{array}{c}\text { Final value of } \\
\text { the Degree of } \\
\text { cumulative } \\
\text { seismic risk }\end{array}$ \\
\hline High risk (E) & Risk built High / Risk Accessibility High & EE & High risk \\
\hline Moderate risk (M) & Risk built High / Risk Moderate accessibility & EM & High risk \\
\hline Low Risk (F) & Risk built High / Risk Low accessibility & EF & High risk \\
\hline- & Moderate Built Risk / Risk Accessibility High & ME & High risk \\
\hline- & Moderate Built Risk / Risk Moderate accessibility & MM & Moderate risk \\
\hline- & Moderate Built Risk / Risk Low accessibility & MF & Low Risk \\
\hline- & low built risk / Risk Accessibility High & FE & Moderate risk \\
\hline- & low built risk / Risk Moderate accessibility & FM & Low Risk \\
\hline- & low built risk / Risk Low accessibility & FF & Low Risk \\
\hline
\end{tabular}

\section{2-4 Presentation of results by cities and districts}

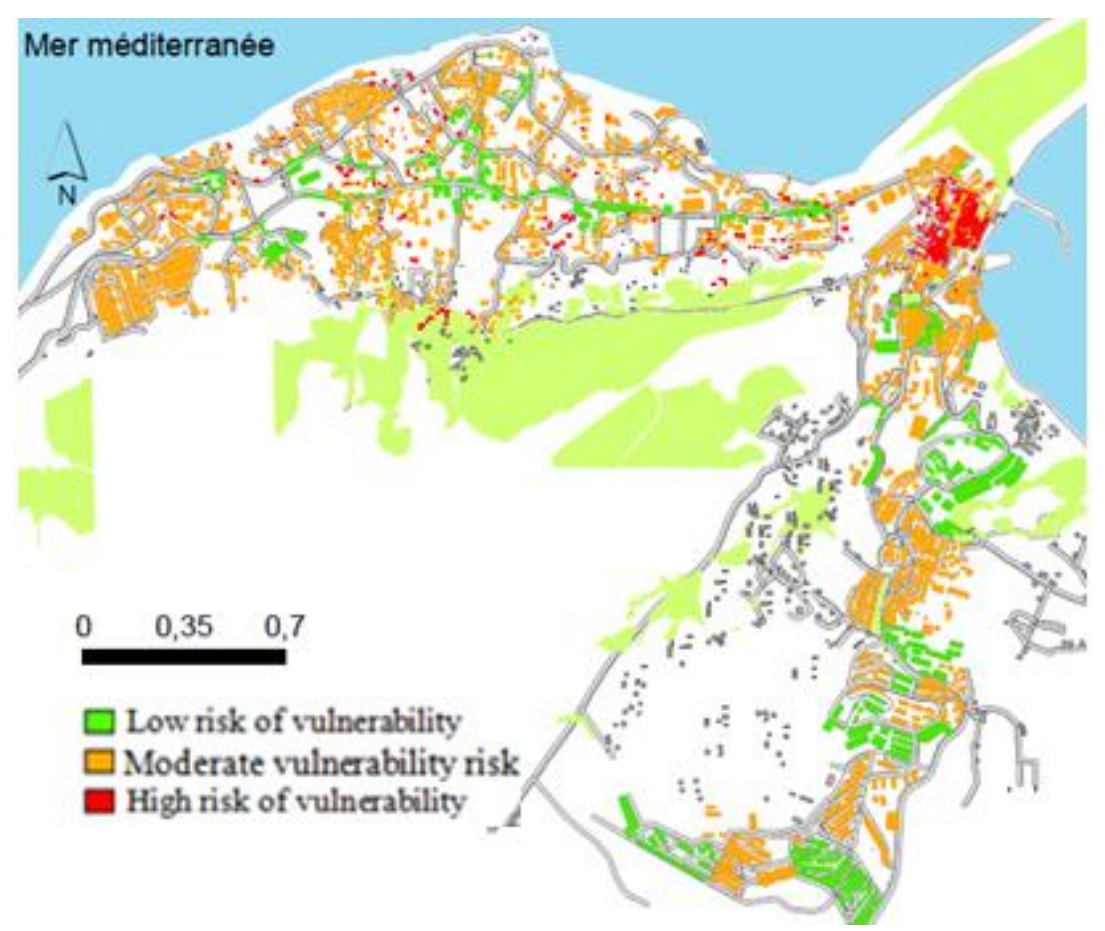

Figure 8: Distribution of the vulnerability of the existing buildings in the city of Dellys 


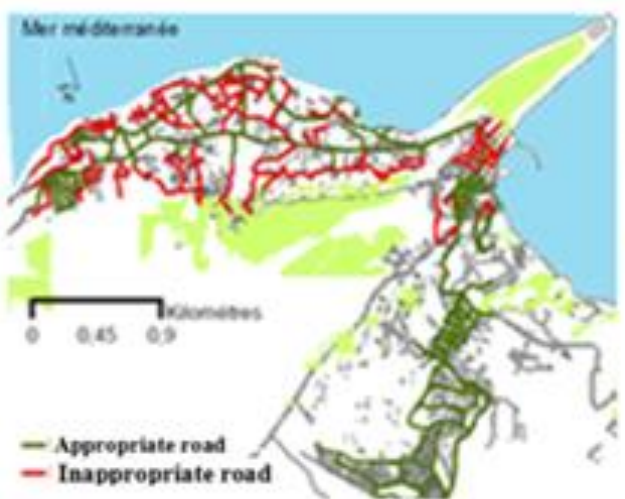

Road network classification

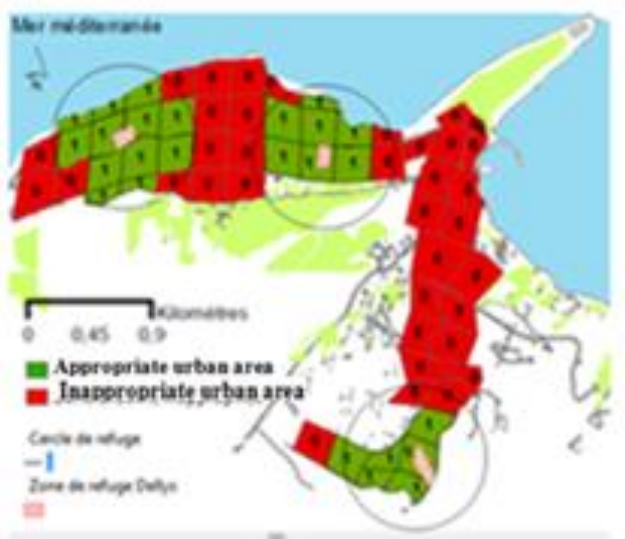

Classitication of urban areas by

, Refuge and emergency evacuation points

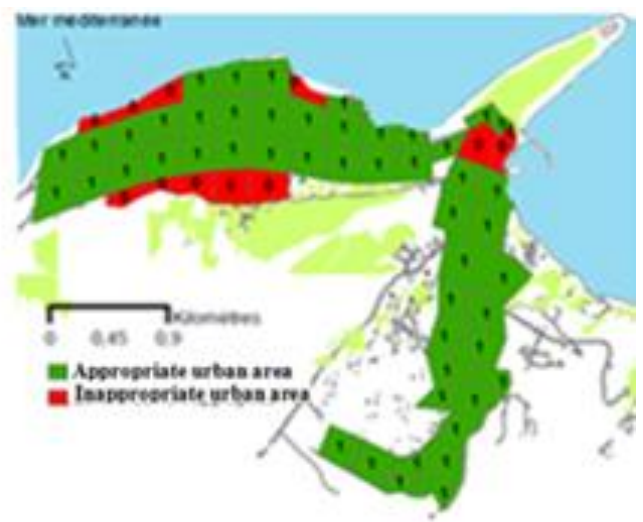

Classification of urban areas by road network

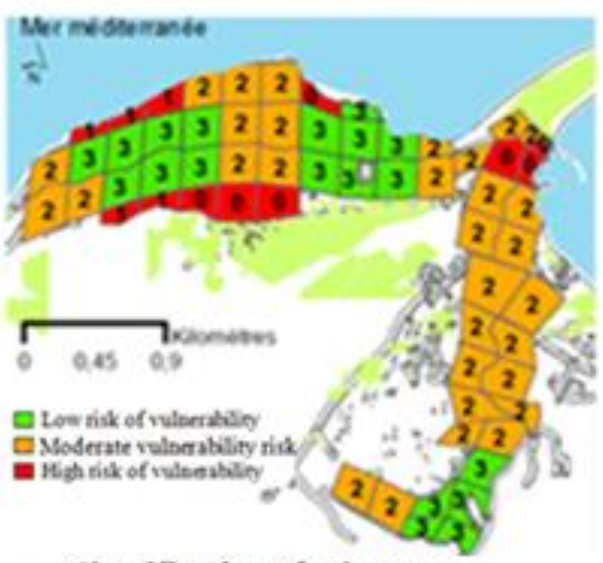

Classification of urban areas with access to evacuation and rescu

Figure 9: Distribution of the vulnerability of the urban system in the city of Dellys

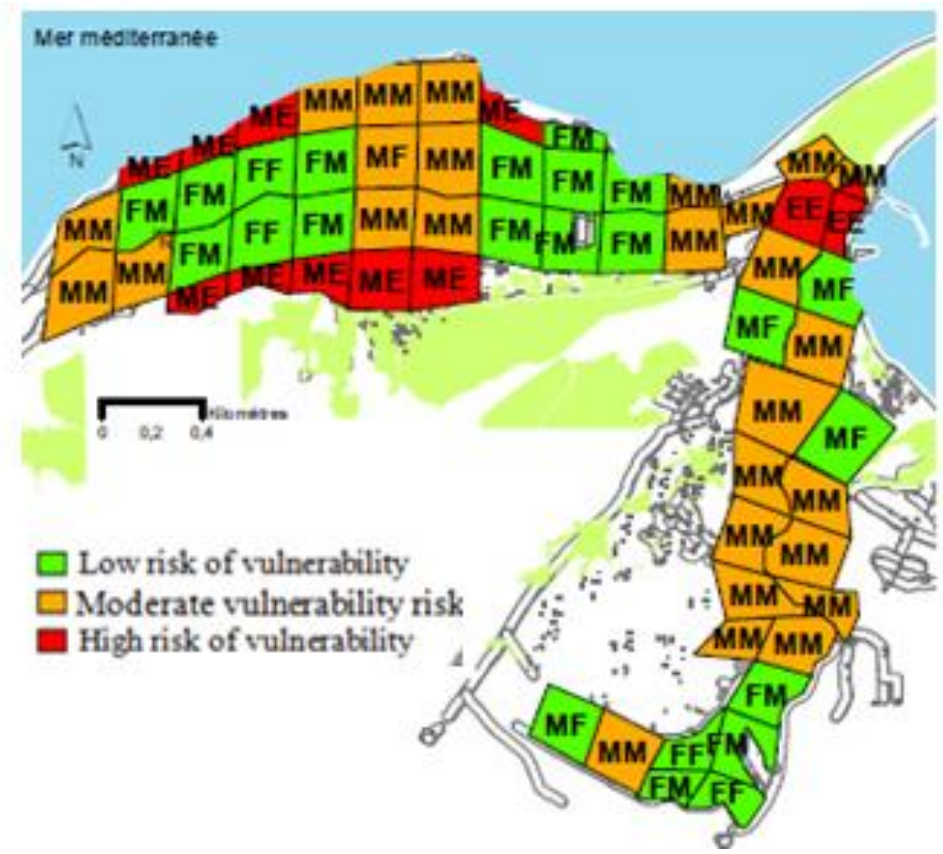

Figure 10: Distribution of urban areas at cumulative seismic risk in the city of Dellys (Overlay of the vulnerability map of the building on the accessibility and emergency capacity map) 

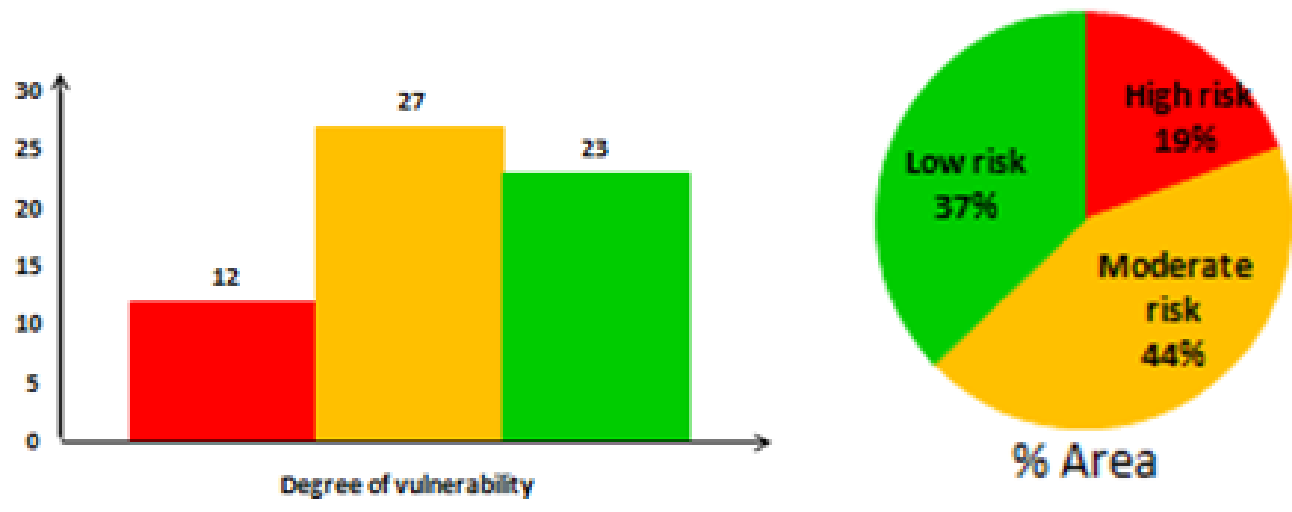

Figure 11: Comparison of observed results from urban areas at cumulative seismic risk in the city of Dellys

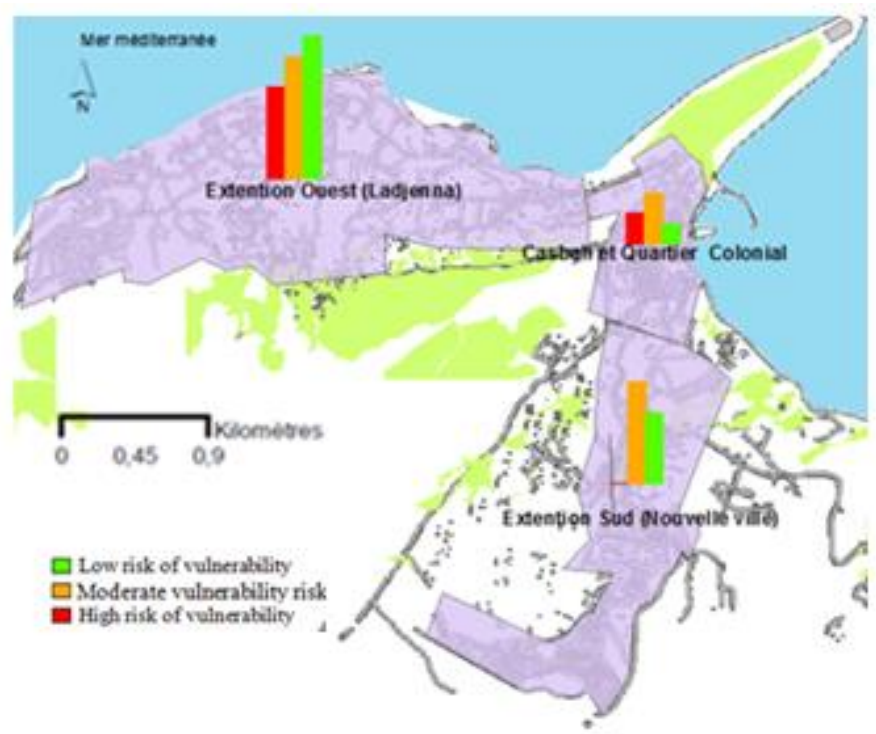

Figure 12: Histogram of urban areas at cumulative seismic risk in the districts of the city of Dellys
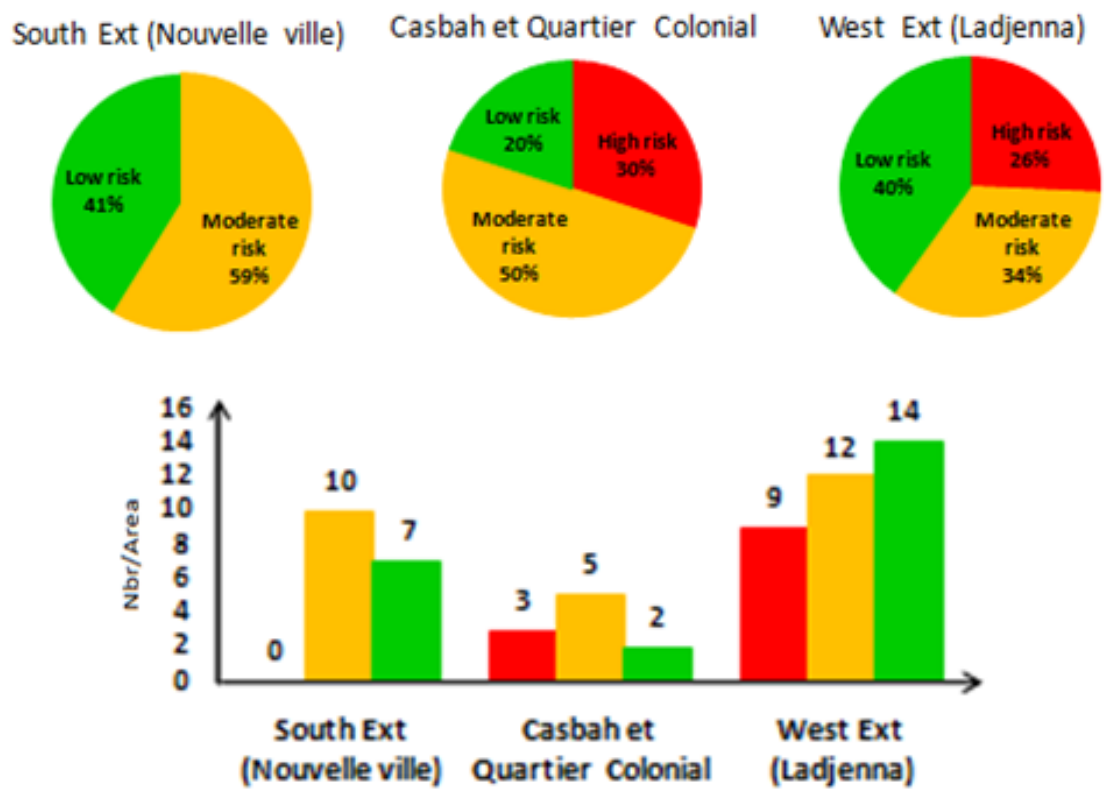

- High risk Moderote risk = Low risk

Figure 13: Comparison of observed results from urban areas at cumulative seismic risk in the districts of the city of Dellys 


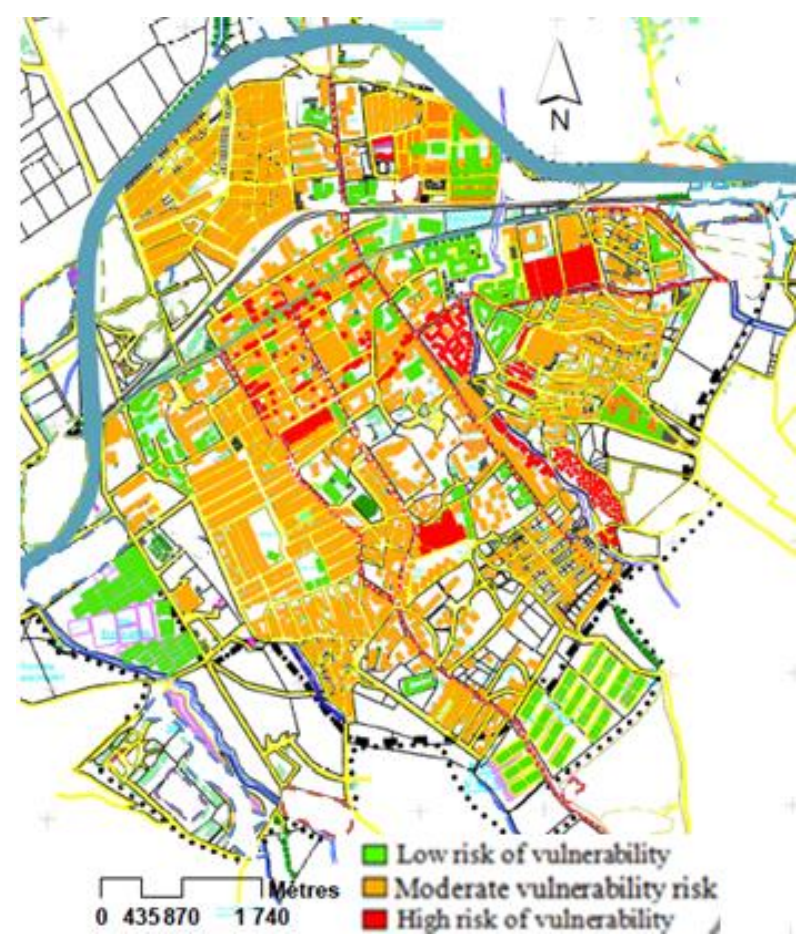

Figure14: Distribution of the vulnerability of the existing buildings in the city of Bordjménail

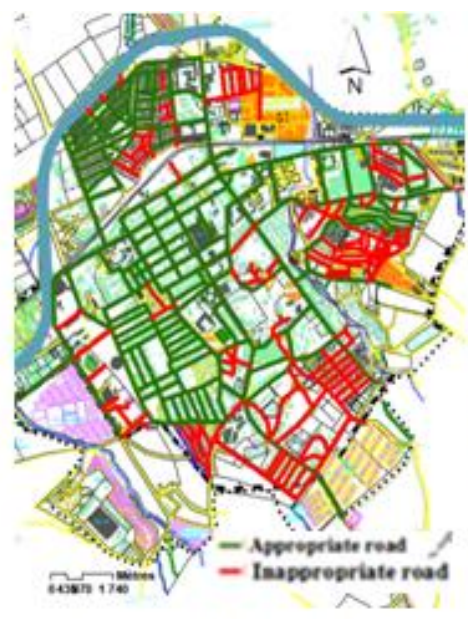

Road network classification

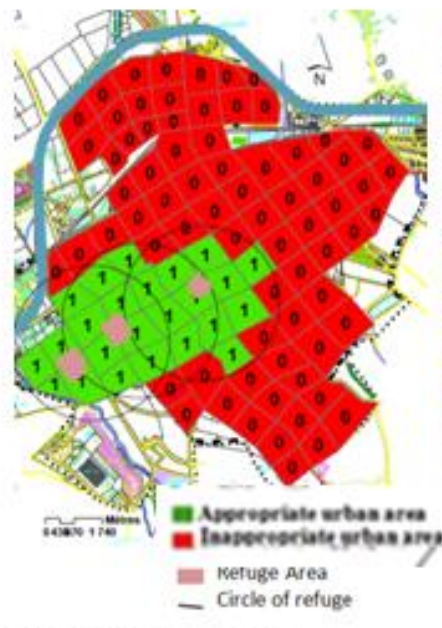

Classitication of urban areas by Refuge and emergency evacuation points
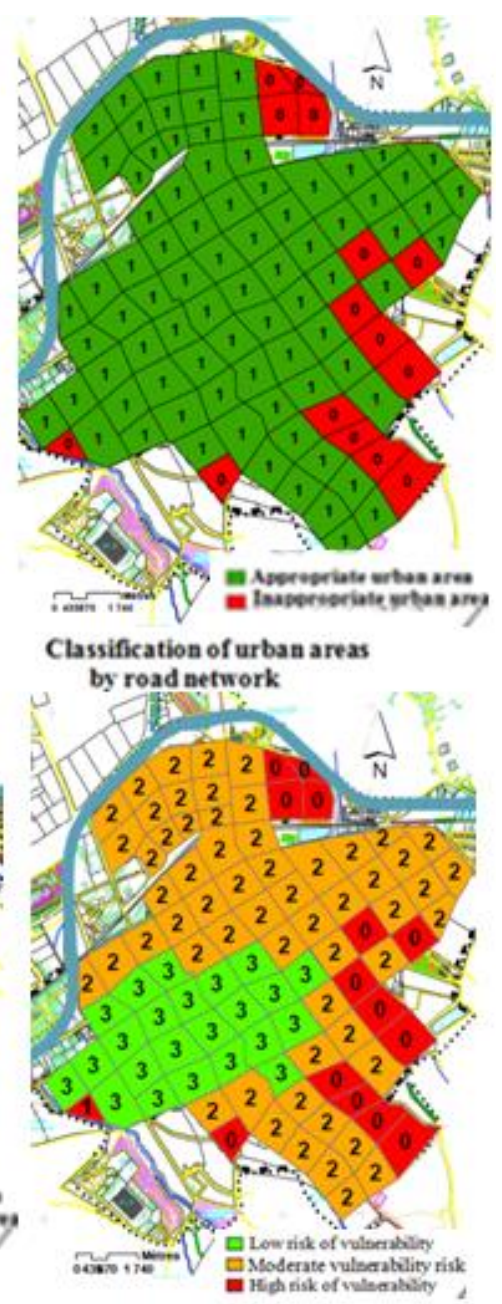

Classification of urban areas with access to evacuation and rescu

Figure 15: Distribution of the vulnerability of the urban system in the city of Bordjménail 


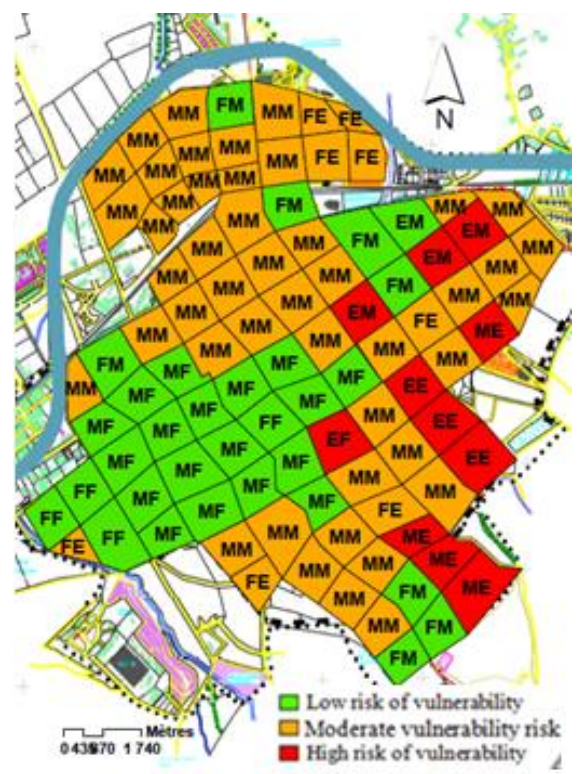

Figure 16: Distribution of urban areas at cumulative seismic risk in the city of Bordjménail (Overlay of the vulnerability map of the building on the accessibility and emergency capacity map)
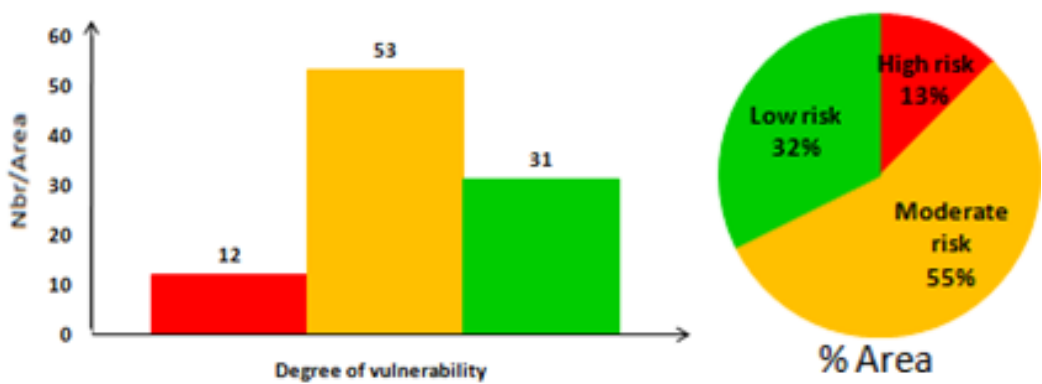

Figure 17: Comparison of observed results from urban areas at cumulative seismic risk in the city of Bordjménail

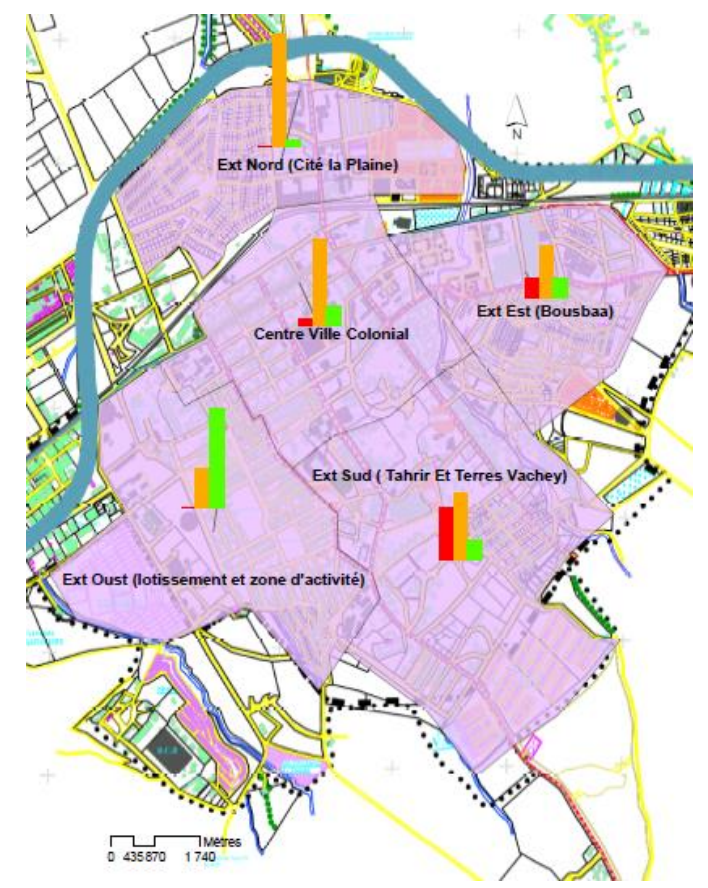

Figure 18: Histogram of urban areas at cumulative seismic risk in the districts of the city of Bordjménail 

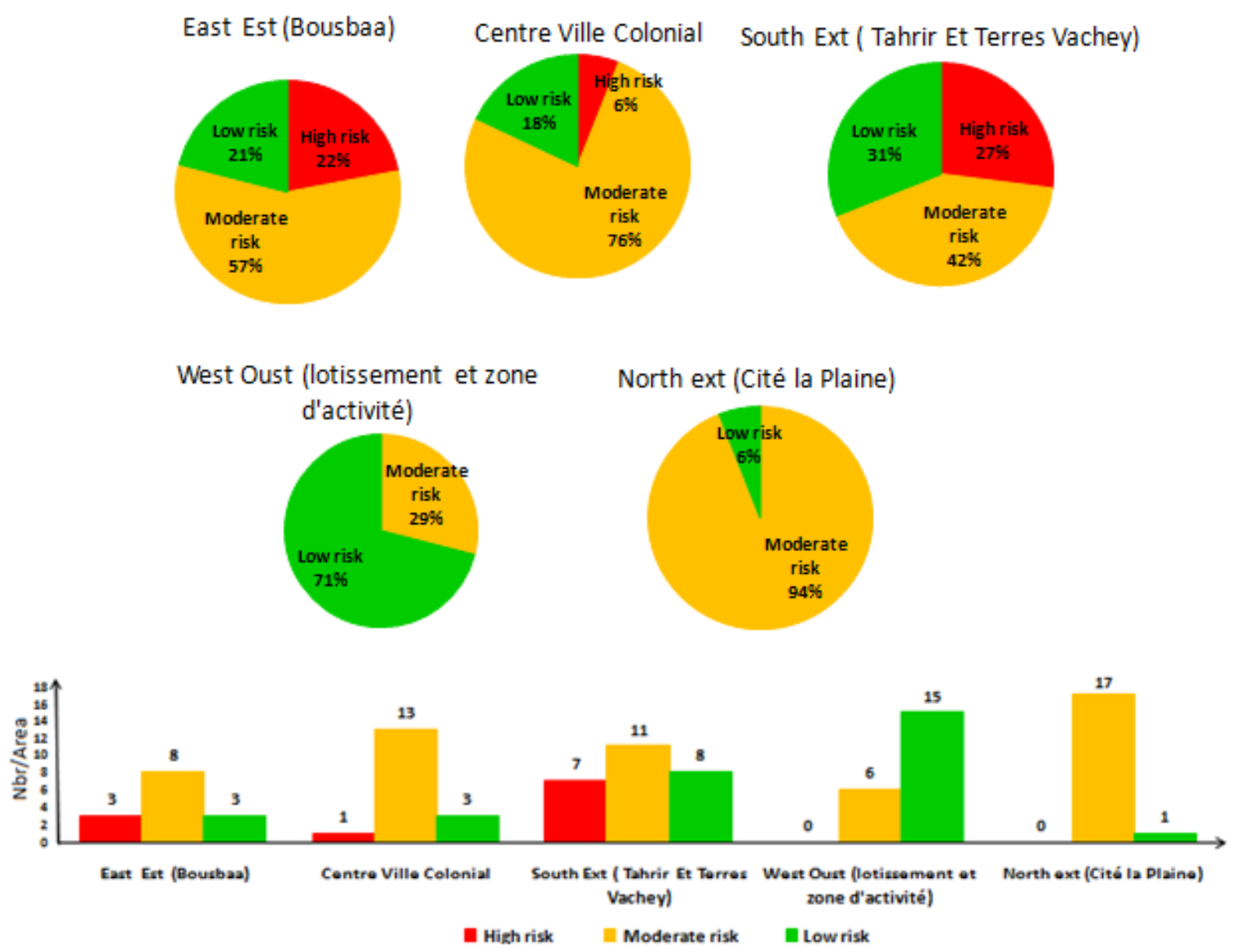

Figure 19: Comparison of observed results from urban areas at cumulative seismic risk in the districts of the city of Bordjménail

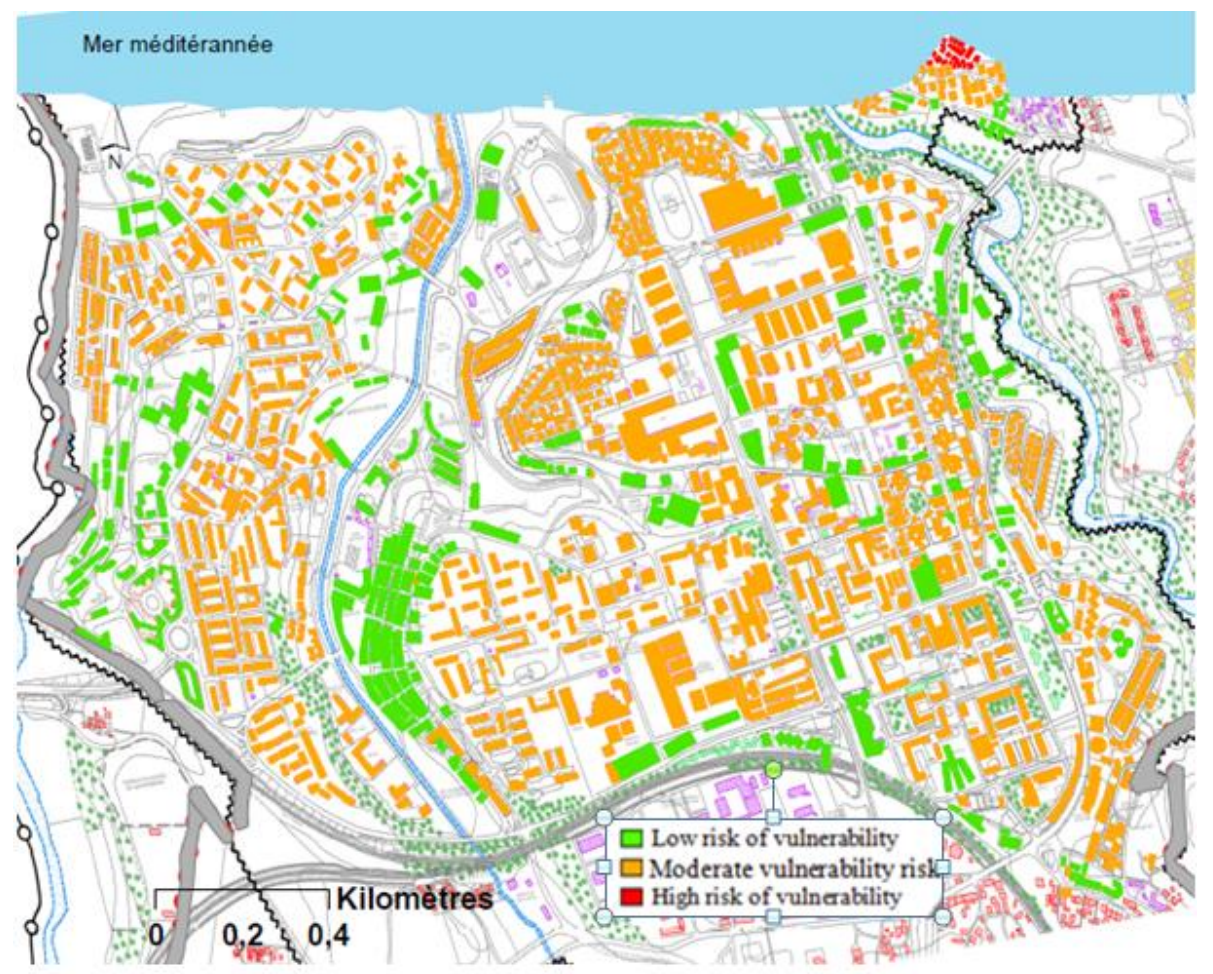

Figure20: Distribution of the vulnerability of the existing buildings in the city of Boumerdés 


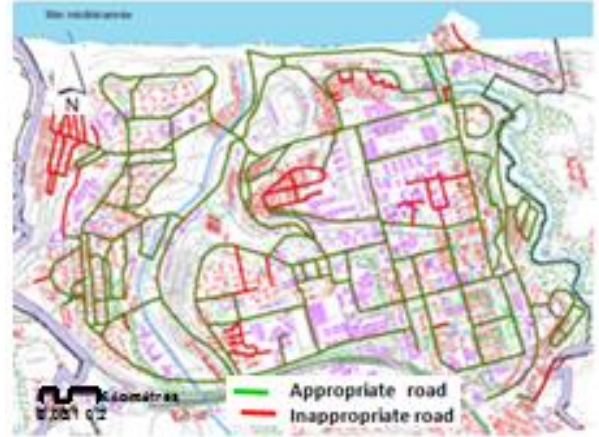

Road network classification

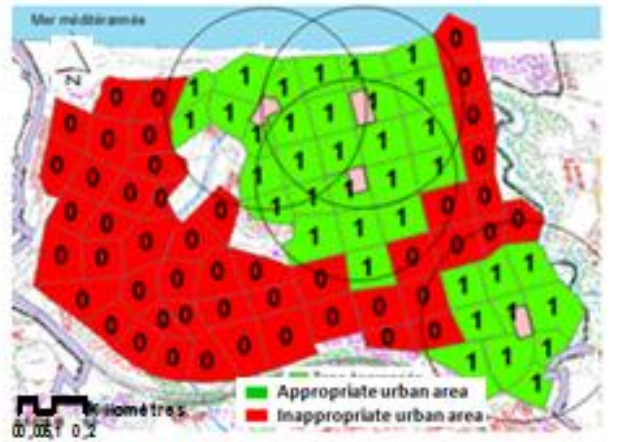

Classitication of urban areas by

Refuge and emergency evacuation points
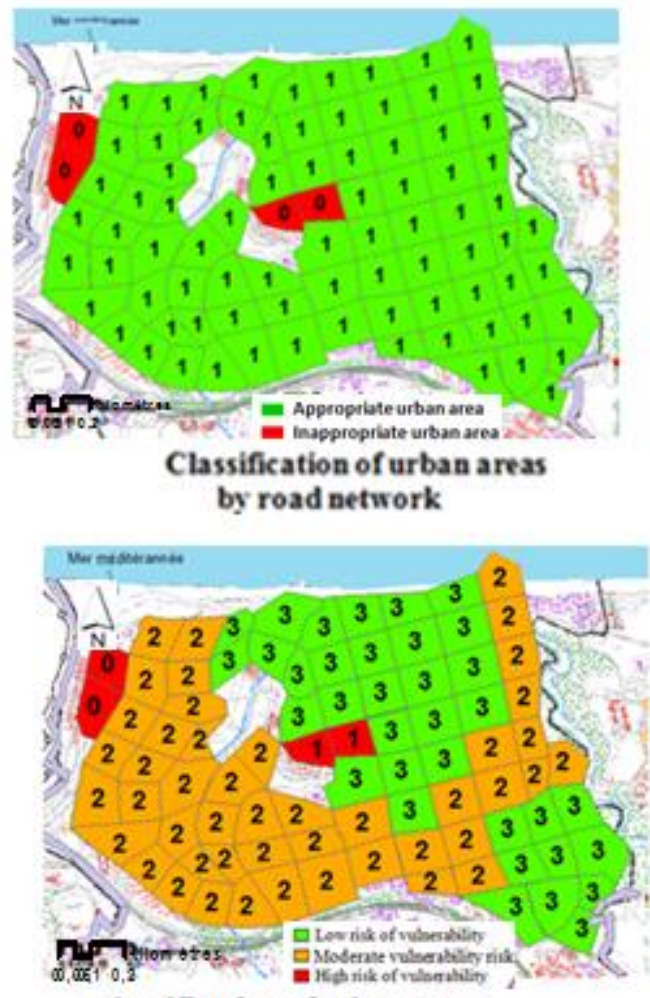

Classification of urban areas

with access to evacuation and rescu

Figure 21: Distribution of the vulnerability of the urban system in the city of Boumerdés

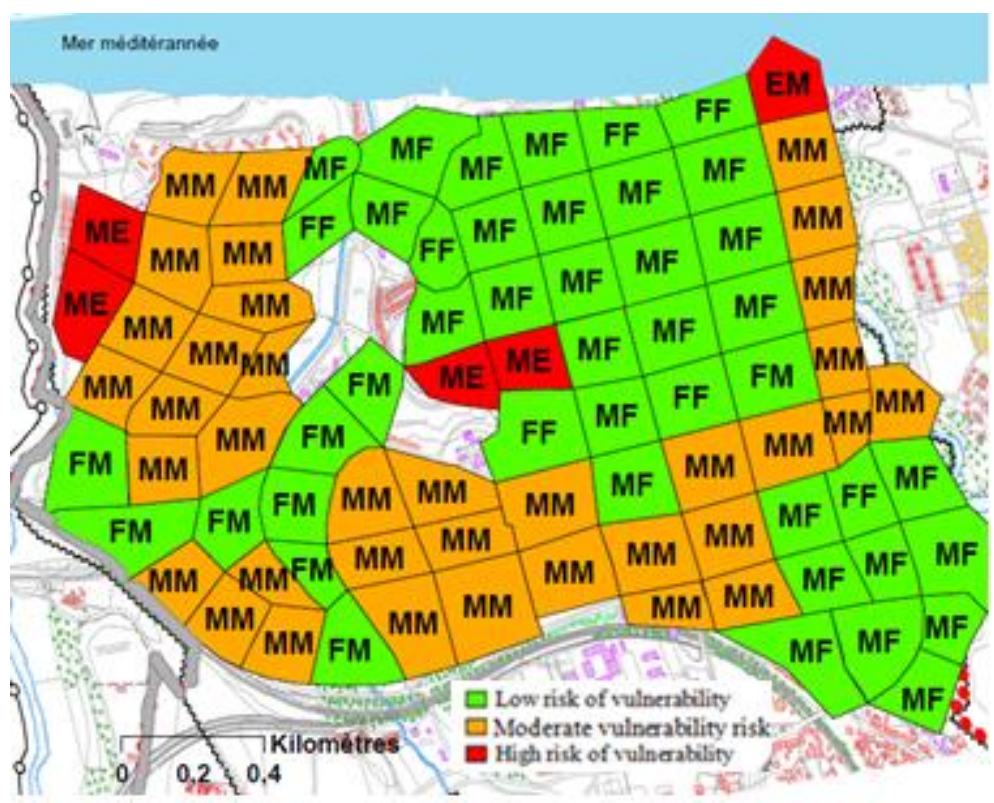

Figure 22: Distribution of urban areas at cumulative seismic risk in the city of Boumerdés (Overlay of the vulnerability map of the building on the accessibility and emergency capacity map) 

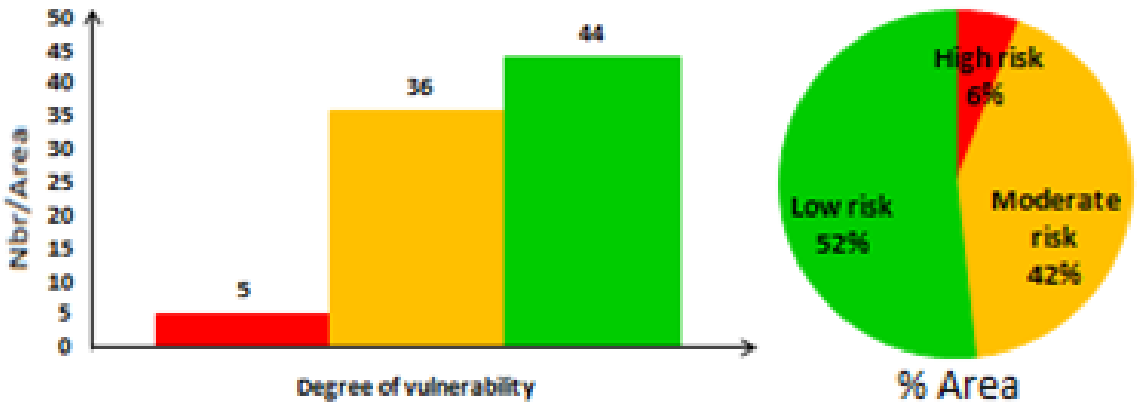

Figure 23: Comparison of observed results from urban areas at cumulative seismic risk in the city of Boumerdés

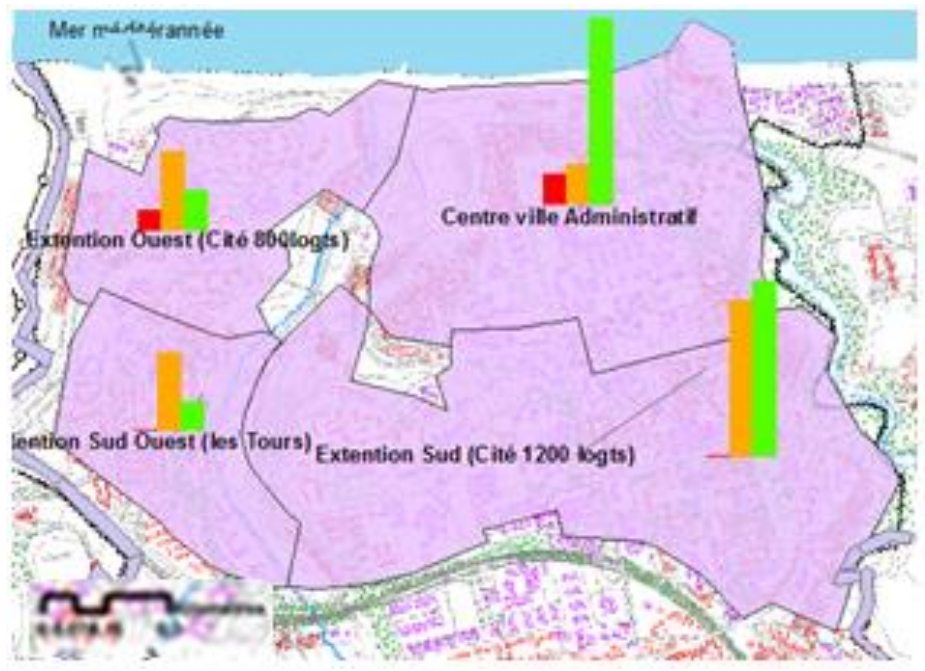

Figure 24: Histogram of urban areas at cumulative seismic risk in the districts of the city of Boumerdés
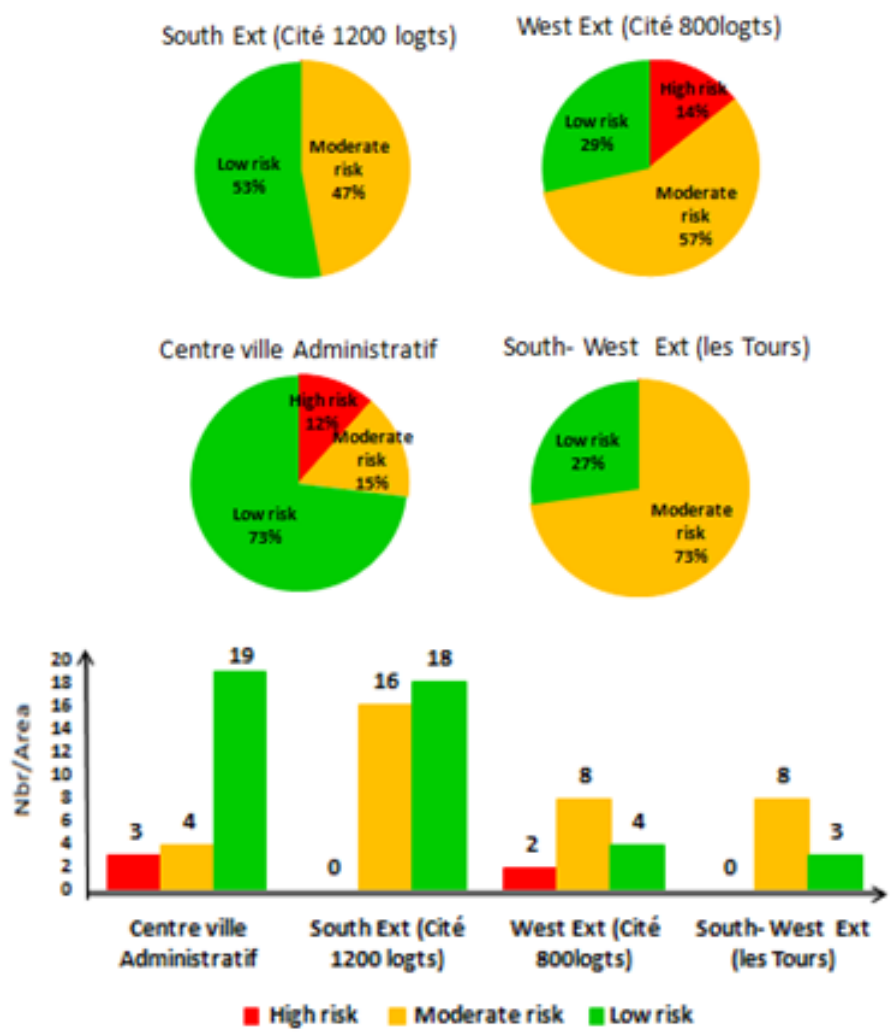

Figure 25: Comparison of observed results from urban areas at cumulative seismic risk in the districts of the city of Boumerdés 


\section{2-5 Presentation of results by region}

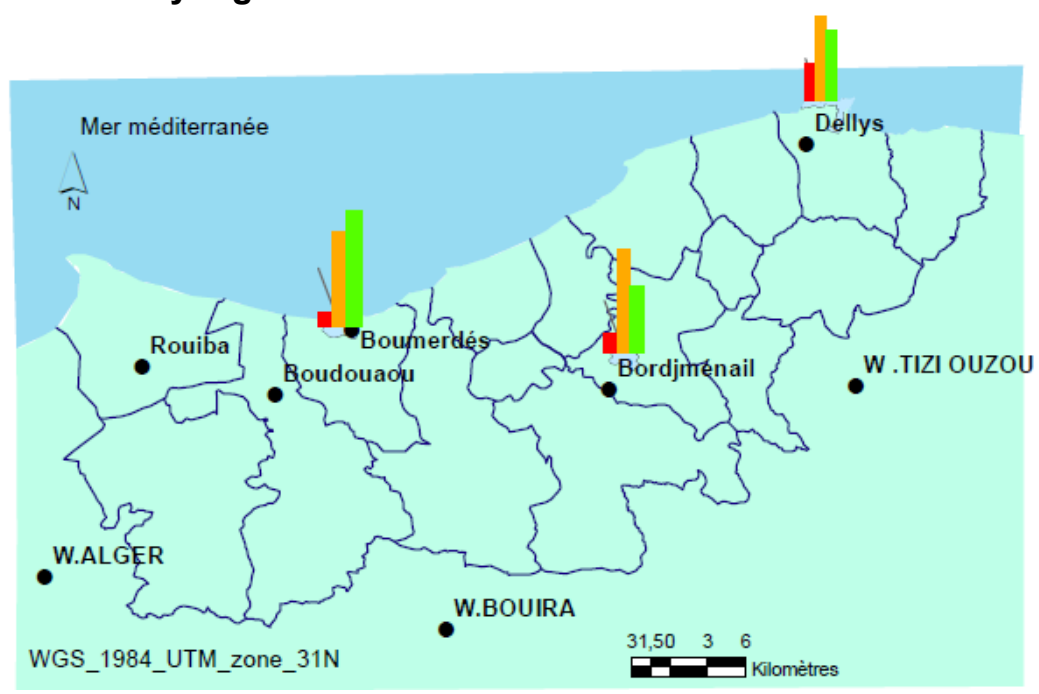

Figure 26: Distribution of urban areas at risk by city in the study area

- Regional ranking of cities with high cumulative seismic risk (EE, EM, EF and ME) in order of vulnerability

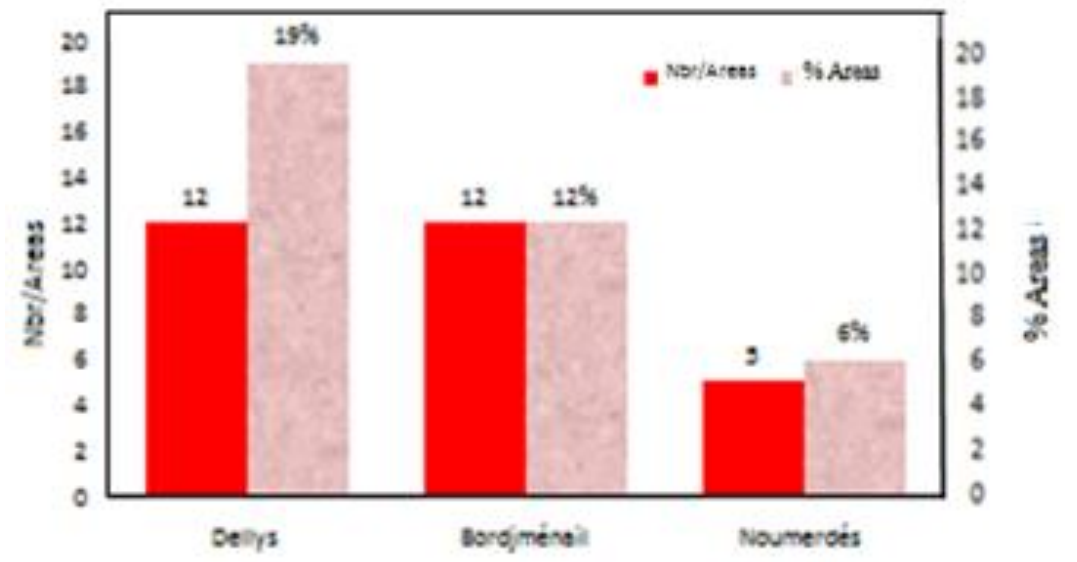

Figure 27: Histogram of cities at cumulative seismic risk by order of vulnerability

- Regional ranking of districts at high cumulative seismic risk in order of vulnerability:

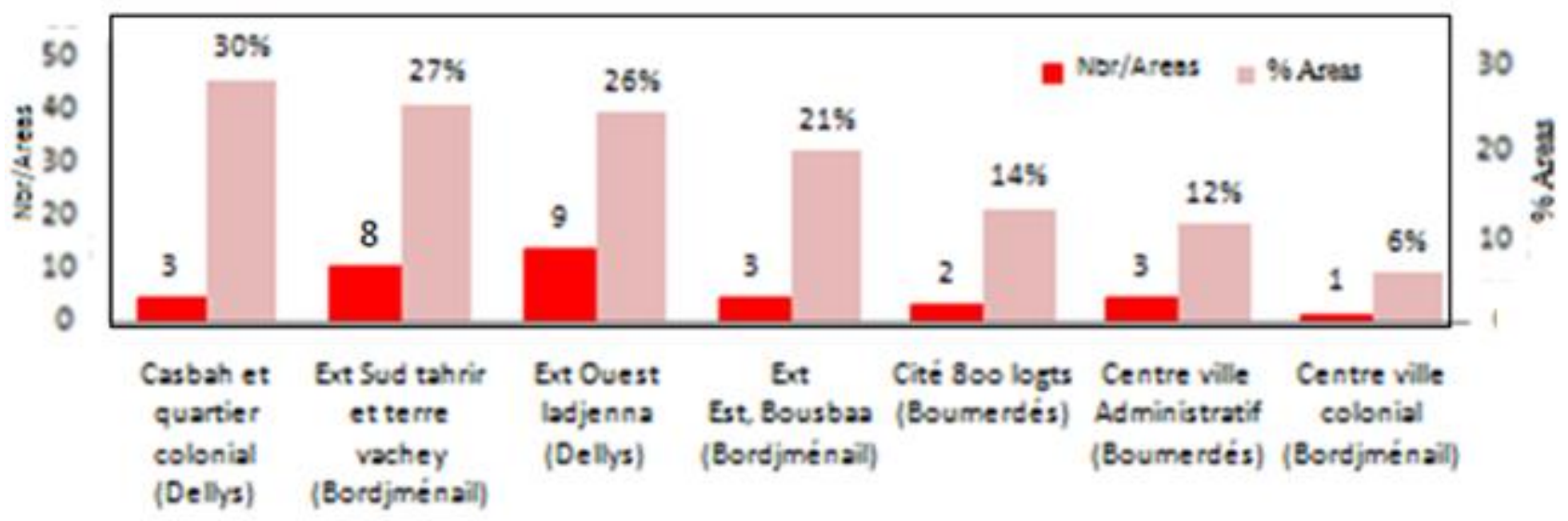

Figure 28: Histogram of districts at cumulative seismic risk by order of vulnerability 
Regional ranking of cities at cumulative seismic risk by type of vulnerability: (Built vulnerability (EM+EF), vulnerability of accessibility to rescue (ME) and cross vulnerability (EE))

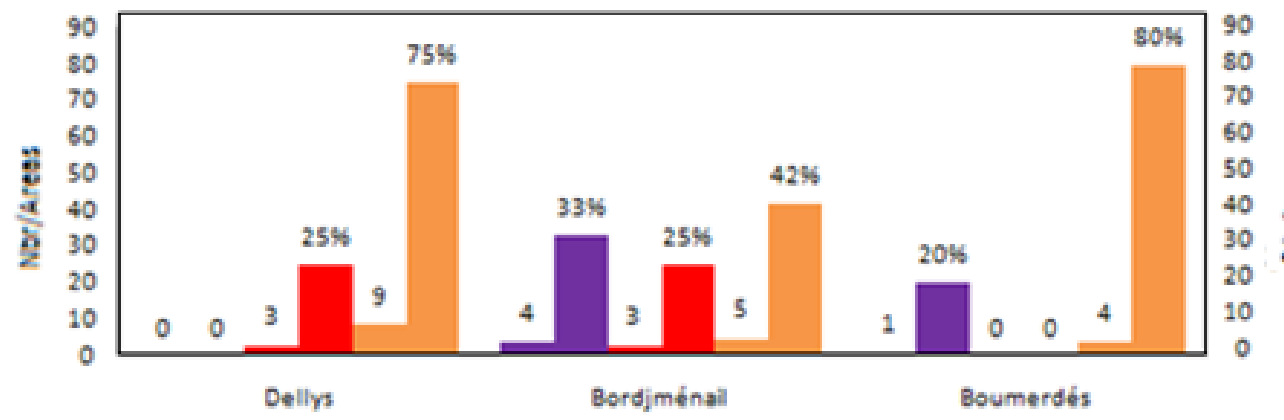

-Built vulnerability | mcross vulnerability | vulnerability of accessibility to rescue 3 =

Figure 29: Histogram of cities at cumulative seismic risk by type of vulnerability

Regional ranking of districts at cumulative seismic risk by type of vulnerability:

(Built vulnerability (EM+EF), vulnerability of accessibility to rescue (ME) and cross vulnerability (EE)).

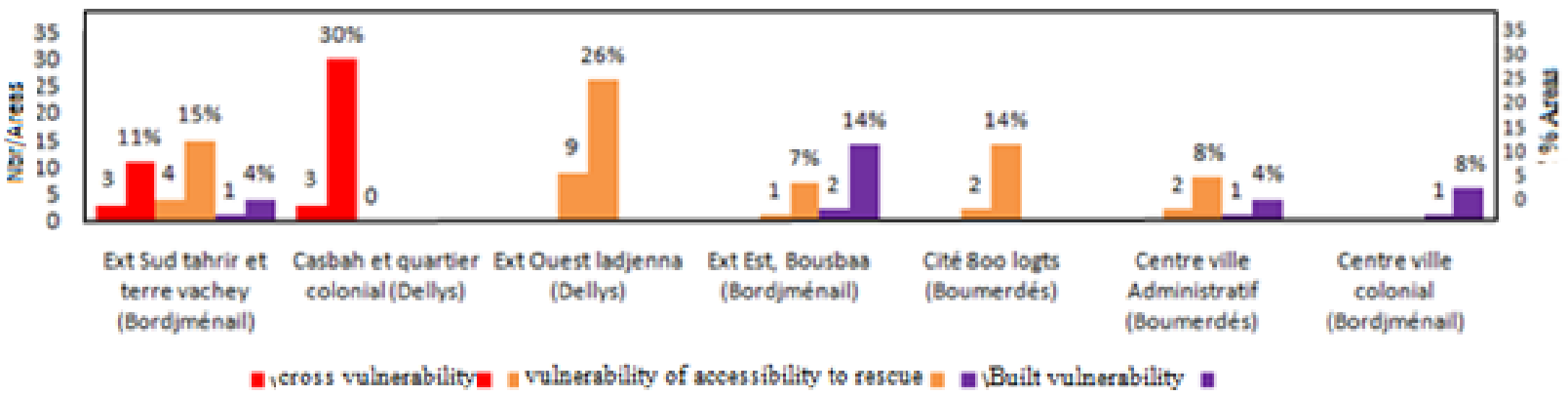

Figure 30: Histogram of districts at cumulative seismic risk by type of vulnerability

\section{3-Discussion:}

Following a scenario earthquake (IX) EMS 98, the results of the superposition of risk maps (vulnerability of the building and capacity for accessibility to rescue), a synthesis of the two evaluations designed using a geographic information system (GIS), show us the following:

1) The geographical in-situ distribution of areas vulnerable to cumulative seismic risk, which allows the location of the existing high-risk building likely to reach level D4 and D5 damage according to the EMS 98 scale, which may encourage preventive interventions to reduce the vulnerability of the building on the one hand and improve the resilience of the urban system in urban areas not suitable for evacuation accessibility and rescue on the other hand (Figure 8/Figure 25).

2) The regional ranking of cities with high cumulative seismic risk (EE, EM, EF and $\mathrm{ME}$ ) in order of vulnerability for the 3 cities has shown that: Dellys is ranked as the most vulnerable with 12 areas for $19 \%$ of the total surface area of the city, followed by Bordjménail which comes with 12 areas for $13 \%$, and last is Boumerdés which is the least vulnerable for only 05 urban areas for $6 \%$ (Figure 27).
3) A regional ranking of districts with high cumulative seismic risk (EE, EM, EF and $\mathrm{ME}$ ) in order of vulnerability at the districts level shows that the degree of vulnerability has been maintained that of cities. The order of districts ranked in the first place is that of the city of Dellys. Its districts located in the Casbah (03 areas for $30 \%$ ) of the total area of the district and ladjenna (09 areas for 26\%). The place of the second city vulnerable goes to Bordjménail thanks toits two districts, Tahrir and Vachey lands (07 areas for 27\%), and Bousbaa district (03 areas for 22\%). The least vulnerable districts are the colonial city centers of Boumerdés $(12 \%)$ and Bordjmenail with (6\%) (Figure 28).

4) A regional classification of cities with a high cumulative seismic risk by nature of vulnerability gave the following results: the Cross-Vulnerability (EE), which combines high vulnerability of the built environment with that of accessibility to relief, particularly affects the two cities of Dellys and Bordjménail with 03 urban areas, i.e. $25 \%$ of the total vulnerable area each. The vulnerability of buildings $(\mathrm{EM}+\mathrm{EF})$ is present in the city of Bordjménail with 04 zones for $33 \%$ total vulnerable area against 01 urban zone for $20 \%$ in Boumerdés. Finally, the vulnerability of 
accessibility to rescue (ME) is particularly the source of seismic risk in the city of Boumerdés with 04 zones for $80 \%$ of the total vulnerable area. It is followed by Dellys, 09 zones for $75 \%$, and then Bordjménail with 05 zones for $42 \%$ (Figure 29).

5) A regional classification of districts with a high cumulative seismic risk by type of vulnerability shows that the order of vulnerability by district has been maintained at the level of cross vulnerability (EE).It is the Kasbah of Dellys which is the most vulnerable with 03 urban areas for $30 \%$ of total vulnerable area. It is then followed by the Tahrir district and Vachey lands of Bordjménail (03 areas for $11 \%)$. The vulnerability of buildings $(\mathrm{EM}+\mathrm{EF})$ has followed the ranking order of cities. it is the Bousbaa district of Bordjménail (02 areas for $14 \%$ ) which is the most vulnerable against the administrative centre of Boumerdés, that is the least vulnerable (with 01 areas for 4\%). The vulnerability of accessibility to relief (ME) did not respect the order of ranking of cities, in fact, the ladjenna district (Dellys) is the most vulnerable (09 areas for 26\%) against the least vulnerable district of Bousbaa de Bordjménail (01 area for $07 \%$ ) (Figure 30).

6) On comparing the results, a difference between the ranking of cities and districts by order and nature of vulnerabilities is noticed. However, the actual assessment of risk areas is closer to the smaller scales of territories such as districts compared to the larger scales of cities.

\section{4- Conclusion:}

The objective of our study is to improve the seismic risk component in Algerian planning and urban development instruments at the regional and local levels. The proposed method enables us to turn the rich and varied datain to graphic and statistical form under multiple hierarchical presentations of the consequences of vulnerabilities at multidimensional scales (Region, city and districts).It is based on an interpretation of the consequences of an earthquake scenario operated according to urban planning priorities that match with the nature of the Algerian planning and urban development instruments. The results obtained from the vulnerability assessments of cities and districts at the regional level may be extrapolated to large-scale studies such as the Wilaya Land Use Plan (PATW) or the Metropolitan Area Master Plan (SDAAM).It is at this scale that preliminary studies optimize the response of territories to earthquakes and direct sensitive cities towards more in-depth analyses. On a smaller scale, the results obtained for cities and districts may include Development and Urban Planning Plans (PDAU) or Land Use Plans (POS).Locating elements at risk in situ may lead to preventive measures such as strengthening existing buildings or improving the resilience of the urban system and developing refuge areas for disaster victims or widening streets to facilitate emergency roads.
Our method is limited by nature due to its urban-scale study, which is the least practiced at present. Also, the lack of urban evaluations in the region does not allow the results found to be validated. Another limit consists of the evaluation of the existing building, although calculated according to a referential method (RiskEU). The results where the damage obtained is related to the vulnerability index for each constructive typology and not to the probabilities of damage likely to occur, given that structures of the same typology do not behave in the same way with regard to earthquakes.

In any case, the approach presented can be adopted for the prioritization of vulnerable urban areas in the city. It therefore serves as a tool to take into account seismic risks in Algerian planning and urban planning instruments .As a post-study, we intend to quantify the economic value and prioritize the importance of risk factors located in vulnerable urban areas through a closer look at the actual field data in research work.

\section{Bibliography :}

[1], Inter-municipal Master Plan for Développent and Urban Planning (PDAU):Boumerdés Corso and Tidjelabine, chapter I, "État de fait, diagnostic et options d'aménagement" p 55 and "Milieu et ressources naturelles" p 72, Plan Directeur d'Aménagement et d'Urbanisme (PDAU) Dellys, chapter I, Données Physiques de la commune p 39 Plan Directeur d'Aménagement et d'Urbanisme (PDAU) de Bordjménail chapter II, "Données Physiques et Spatiales" p 45.

[2] Algerian Parismic Rules RPA99/version 2003, DTRB.C.2.48 Chapter III (p 14)

[3] Y.Chaid-Saoudi. (2008), Dellys aux milles temps, Tell Edition, p144

[4] Official Gazette of the People's Democratic Republic of Algeria, O.J. Executive Decree N $N^{\circ}$. 07-276 of 18 September (2007)

[5] M.Zacek (1996) Construire Parasismique, Editions parenthèses (France) p 279

[6] Territorial Development Plan of the Wilaya of Boumerdés (PATWB 2012), Volume II, Chapter 1, p 208 and Chapter II p 268

[7] EMS98, "The European Macroseismic Scale 1998", Council of Europe, Cahiers du Centre Européen de Géodynamique et de Séismologie, Volume 19, (2001)

[8] K.Ramdan (2003) Alger-Boumerdés, Algeria earthquake of may 21 2003, CGS-CTC mission report 
[9] Japan International Cooperation Agency (JICA) Centre National de Recherche Appliquée en Genie Parasimmique (CGS), Seismic Microzoning Study of the Wilaya of Algiers (Algeria) (2006), Final Report Volume IV ,06-078

[10] 0.Sedan et al (2005), Etude de réduction de la vulnérabilité du massif de Bouzaréah aux catastrophes naturelles, Rapport BRGM/RC-54378-FR, BRGM\&ISL.

[11] ATC 21, " Rapid Visual screening of buildings for potential seismic hazards: a handbook ", Applied Technology Council, Redwood City, California, (1988).

[12] GNDT, " Rischio Sismico di Edifici Pubblici - Parte I: aspetti metodologici ", Centro Servizi Quasco, Bologna, (1993)

[13] Z.Milutinovic. et G. S. Trendafiloski (2003) WP4 : Vulnérabilité des bâtiments actuels. Projet Risk-UE : Une approche avancée des scénarios de risques sismiques avec des applications http://www.risk-ue.net.

[14] M. ZACEK Milan (2003) Conception parasismique, niveau avant-projet. Cahier 1 des cahiers parasismiques Les grands ateliers de l'Isle d'Abeau, 89 p.

[15] A.Ayadi A. et M.Bezzeghoud (2015), Sismicité de l'Algérie de 1365 à 2013 : Carte d'intensité maximale observée (d'ici 2014), Seismological Research Letters Vol. 86, No.1, pp.1-9 